\title{
Plant Derived Bioactive Compounds, Their Anti-Cancer Effects and In Silico Approaches as an Alternative Target Treatment Strategy for Breast Cancer: An Updated Overview
}

\author{
Vijayakumar Shrihastini ${ }^{1}$, Pandiyan Muthuramalingam ${ }^{1, * \mathbb{C}}$, Sivakumar Adarshan ${ }^{2} \mathbb{D}$, Mariappan Sujitha ${ }^{1}$, \\ Jen-Tsung Chen ${ }^{3, *}\left(\mathbb{D}\right.$, Hyunsuk Shin ${ }^{4}\left(\mathbb{D}\right.$ and Manikandan Ramesh ${ }^{2}(\mathbb{D})$ \\ 1 Department of Biotechnology, Sri Shakthi Institute of Engineering and Technology, \\ Coimbatore 641062, Tamil Nadu, India; shrihastinivijayakumar@gmail.com (V.S.); \\ psujitha1325@gmail.com (M.S.) \\ 2 Department of Biotechnology, Science Campus, Alagappa University, Karaikudi 630003, Tamil Nadu, India; \\ sadarshan1999@gmail.com (S.A.); mrbiotech.alu@gmail.com (M.R.) \\ 3 Department of Life Sciences, National University of Kaohsiung, Kaohsiung 811, Taiwan \\ 4 Department of Horticultural Sciences, Gyeongsang National University, Jinju 52725, Korea; \\ shinpomo@gnu.ac.kr \\ * Correspondence: pandianmuthuramalingam@gmail.com (P.M.); jentsung@nuk.edu.tw (J.-T.C.)
}

Citation: Shrihastini, $\mathrm{V}$; Muthuramalingam, P.; Adarshan, S.; Sujitha, M.; Chen, J.-T.; Shin, H.; Ramesh, M. Plant Derived Bioactive Compounds, Their Anti-Cancer Effects and In Silico Approaches as an Alternative Target Treatment Strategy for Breast Cancer: An Updated Overview. Cancers 2021, 13, 6222. https://doi.org/10.3390/ cancers 13246222

Academic Editors: Konstantina Karamanou, Stamatis Rigas and Polydefkis Hatzopoulos

Received: 4 November 2021 Accepted: 9 December 2021 Published: 10 December 2021

Publisher's Note: MDPI stays neutral with regard to jurisdictional claims in published maps and institutional affiliations.

Copyright: (c) 2021 by the authors. Licensee MDPI, Basel, Switzerland. This article is an open access article distributed under the terms and conditions of the Creative Commons Attribution (CC BY) license (https:// creativecommons.org/licenses/by/ $4.0 /)$.
Simple Summary: Breast cancer is one of the leading causes of death among women worldwide. Breast cancer may be provoked due to several physical, chemical and environmental factors. Moreover, genetic alternations that are inherited via generations may be a reason for the occurrence of cancer. When the cancer is benign, several therapeutic approaches are available to treat it. In case of malignancy, cancer may spread to other body parts and lead to death. Recent studies focus on the use of indigenous medicinal plants for the treatment of various cancers and particularly breast cancer. This could be an alternative to other treatment methods, as they cause minimal side effects when compared to chemo-drugs. In addition to that, high-throughput omics tools have paved the way for efficient drug targeting, and it would be a promising application for finding the interaction of drug molecules in human systems.

Abstract: Cancer is one of the most common malignant diseases that occur worldwide, among which breast cancer is the second leading cause of death in women. The subtypes are associated with differences in the outcome and were selected for treatments according to the estrogen receptor, progesterone receptor, and human epidermal growth factor receptor. Triple-negative breast cancer, one of the subtypes of breast cancer, is difficult to treat and can even lead to death. If breast cancer is not treated during the initial stages, it may spread to nearby organs, a process called metastasis, through the blood or lymph system. For in vitro studies, MCF-7, MDA-MB-231, MDAMB-468, and T47B are the most commonly used breast cancer cell lines. Clinically, chemotherapy and radiotherapy are usually expensive and can also cause side effects. To overcome these issues, medicinal plants could be the best alternative for chemotherapeutic drugs with fewer side effects and cost-effectiveness. Furthermore, the genes involved in breast cancer can be regulated and synergized with signaling molecules to suppress the proliferation of breast cancer cells. In addition, nanoparticles encapsulating (nano-encapsulation) medicinal plant extracts showed a significant reduction in the apoptotic and cytotoxic activities of breast cancer cells. This present review mainly speculates an overview of the native medicinal plant derived anti-cancerous compounds with its efficiency, types and pathways involved in breast cancer along with its genes, the mechanism of breast cancer brain metastasis, chemoresistivity and its mechanism, bioinformatics approaches which could be an effective alternative for drug discovery.

Keywords: breast cancer; triple-negative breast cancer; metastasis; medicinal plants; bioinformatics 


\section{Introduction}

Since the start of their existence, human beings have explored a variety of plant species for curing illnesses and improving health [1]. As a result, they have identified a huge array of bioactive compounds with extensive therapeutic potentials in plants. Flavonoids, carotenoids, alkaloids, and phenolics are some of the most highly researched plant chemicals with a wide range of medicinal properties including antitumor activity [2-4]. Cancer, the second-most leading cause of mortality, is a genetic disease that is caused due to uncontrolled proliferation of abnormal cells in the body and the metastasis of these cells to other body parts [5], among which breast cancer is one of the most common type. Breast cancer is an example of a heterogeneous disease caused among women. After skin cancer, the second most commonly diagnosed is breast cancer. Breast cancer can be divided into four types; (1) luminal A, (2) luminal B, (3) basal-like, which is similar to triple-negative breast cancer (TNBC) and (4) human epidermal growth factor receptor (HER2). The cancer types are often associated with estrogen receptor (ER), progesterone receptor (PR), and HER2. The immunohistochemistry (IHC) of these receptor expressions like ER/PR positive or negative and HER2 positive or negative is used for the identification of the breast cancer subtypes [6]. The most aggressive type of breast cancer is TNBC and totals about $15-25 \%$ of all types. TNBC is difficult to treat because it does not have any effect on HER2-therapies and hormones as they lack expression of ER, PR, and HER2 receptors. Breast cancer is a systemic metastatic disease. Mortality due to breast cancer is high and is caused by metastasis [7].

World Health Organization (WHO) reported that there were about 2 million breast cancer incidents and 685,000 deaths globally by the year 2020. Prominent dangerous elements of breast cancer include aging, personal and family history of breast conditions and cancer, inborn genes (BRCA1 and BRCA2 have an increased risk; PTEN, ATM, TP53, CHEK2, STK11, and PALB2 carry a low risk of breast cancer), radiation, and obesity. Estimated danger elements include nulliparous, single pregnancy, not breastfeeding, postmenopausal hormone therapy, oral intake of contraceptives, high fat intake, low fibers intake, liquor, and smoking (https:/ / www.who.int/news-room/fact-sheets/detail/breast-cancer (accessed on 30 October 2021)). A case study in Mexico City reported that obesity and overweight and lactation have a high risk of causing breast cancer in women [8].

Scientists all over the world are involved in immense research to prevent and treat breast cancer. Due to the booming technological advancements, the development of synthetic medicines began and the usage of medicinal plants was forgotten for a long term. However, because of the severe side-effects caused by those synthetic medicines, the potentials of phytomedicine have received increased attention for the past few decades [9]. Plant extracts cause minimal side effects in comparison to chemotherapeutic drugs and therefore, nowadays, natural remedies are preferred [10]. Though natural remedies cannot cure breast cancer, maintaining a proper diet, regular exercise and good sleep will help to fight against cancer. Eating flavonoid-rich vegetables and fruits like onions, eggplant, garlic, potatoes, tomatoes, lettuce, peppers, apple, orange, and aromatic herbs can reduce the risk of breast cancer [11]. Plants have become a non-toxic and safe source of anticancer compounds. Scientific evidence supports that the extracts of various plants can induce apoptosis in cancer cells [12]. However, not all compounds in plants are non-toxic. Several compounds like ricin present in plants can cause severe toxicity [13]. Therefore, proper attention should be given to mining the potential compounds.

European Code Against Cancer reported that about 9\% of breast cancer is caused due to lack of physical activity [14]. The European Journal of Oncology Nursing reported that around three hours of exercise per week reduced the risk of patients suffering from breast cancer. Therefore, the risk of breast cancer can be reduced with routine exercise. Reducing body fat, especially after menopause, can also decrease the risk. Therapeutic approaches for breast cancer consist of surgery, hospitalization, radiation therapy, chemotherapy, and hormone therapy. On the other hand, bioactive compounds from plant source can be 
combined with chemotherapeutic drugs to minimize the side effects. Breast cancer types, genes involved, causes, and cell lines are illustrated in Figure 1.

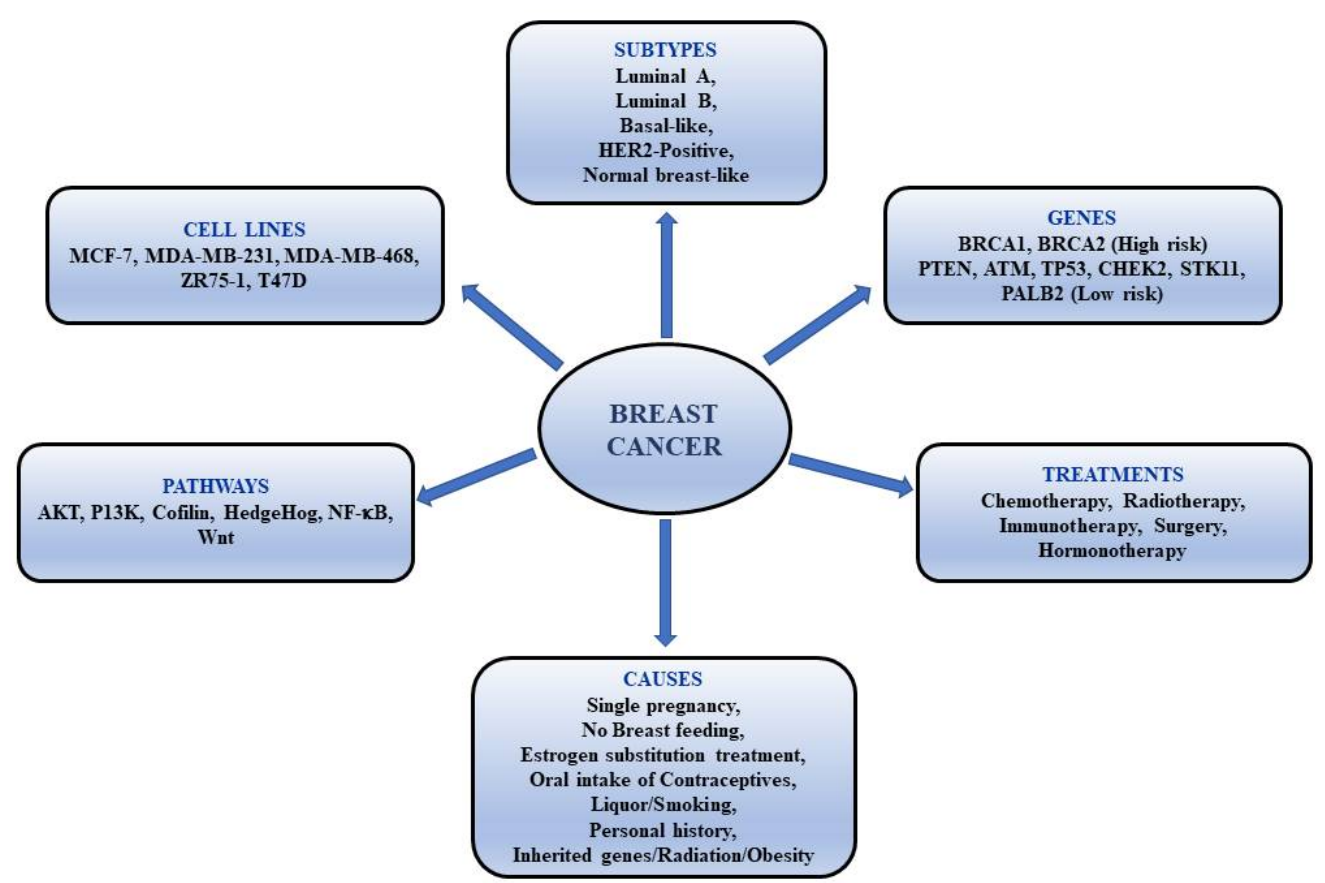

Figure 1. Breast cancer-types, genes involved, causes and cell lines.

Bioinformatics has emerged as a valuable technology in identifying potential molecules and toxic compounds. Bioinformatic techniques such as systems pharmacology and cheminformatics play an important role in the development of novel drug compounds from medicinal plants [15]. These techniques are used to study the interactions between plant compounds and disease-specific human targets, thus contributing significantly to drug discovery. Recent bioinformatics studies depicted the regulatory network between transcriptional factors and immune genes which was useful to understand the immune regulatory mechanisms behind breast cancer. Systems pharmacology and cheminformatics play a major role in drug targeting, finding allosteric binding sites understating, drug efficacy, and toxicity $[16,17]$.

To develop alternative therapeutics for breast cancer, it is important to have deeper understanding on (1) the genes involved in various forms of breast cancer and their originating cell with an immunohistochemical classification of receptors (2) pathways of breast cancer-Akt, cofilin, Hedgehog, nuclear factor-kB (NF-kB), PI3K, PI3K-Akt, PI3KAkt-mTOR, and Wnt (3) mechanisms and genes or molecules that are responsible for breast cancer brain metastasis, (4) chemoresistivity-mechanism and drug/gene, (5) anticancer activity of medicinal plants along with its efficiency, (6) in silico approaches-system pharmacology and cheminformatics, and (7) statistical analysis of breast cancer individually and in comparison with other cancers.

Hence, this review focuses on the divergent aspects to develop therapeutics for breast cancer with special significance given to plant-based-medicinal compounds and bioinformatics. It also focuses on alternative methods and the most efficient ways to develop drugs for breast cancer with minimal side effects.

\section{Sources and Methodology}

The highly relevant articles were retrieved via meticulous search on the databases, Web of Science, Scopus, PubMed, PubChem and Google Scholar. The keywords and phrases were used for the search are "anticancer activity", "medicinal plants", "breast cancer", "anticancer plants", "breast cancer genes and chemoresistivity", "in vitro and 
in vivo activities". The relevant articles number finalized after collated article extraction and analysis through combination of aforementioned keywords and the inclusion criteria was 146. The inclusion criteria were based on the following criteria (i) reported traditional anti-cancerous activity of plants, (ii) reported anti-cancerous role of extract from medicinal plants. The inclusion criteria were implied for selecting particular anticancer plants and their bioactives are given in detail.

\section{Subtypes of Breast Cancer}

\subsection{Luminal $A$}

Luminal A is the common subtype of breast cancer that comprises around $50-60 \%$ of all cases. High ER level and low proliferation genes level are the attributes of luminal A. In addition, expression of cytokeratins [18,19], luminal-associated markers such as ER1, ER function-associated genes including hepatocyte nuclear factor 3 alpha (FOXA1) and B cell lymphoma 2 (BCL2) are the characterizations of Luminal-A [20]. Recent research has identified NCAM1 and NMUR1 as novel genes involved in luminal A cancer [21].

\subsection{Luminal $B$}

Luminal B is the most aggressive type and represents $15-20 \%$ of breast cancers [20]. High expression of proliferation-related genes such as, avian myeloblastosis viral oncogene homolog ( $v$-MYB), gamma-glutamyl hydrolase (GGH), lysosome-associated transmembrane protein 4-beta (LAPTMB4), nuclease sensitive element-binding protein 1 (NSEP1), and cyclin E1 (CCNE1) in luminal B is the main difference between both luminal subgroups [18].

\subsection{Basal-like}

Basal-like tumors represents $8-37 \%$ of all breast cancers [20,22]. Approximately 20-30\% discordance is studied between triple-negative and basal-like. Triple-negative refers to the immunohistochemical classification of breast tumors that are lacking ER, PR, and HER2 protein expression, whereas the basal-like subtype is defined through gene expression microarray analysis [23]. Basal-like breast cancer possesses the most aggressive clinical features. Since there is no effective treatment including radiotherapy, TNBC is difficult to treat. It showed Keratin 5/6 and 17 and EGFR-positivity [24]. Jia et al., has reported that the gene STIL plays a significant role in the basal-like subtype [21].

\subsection{HER2-Positive}

The human epidermal growth factor receptor-2 belonging to tyrosine kinases family, located in chromosome 17q21 is encoded by the HER2 gene [19,25]. HER2-positive represents $15-25 \%$ of breast cancer subtypes and has aggressive biological and clinical behavior [25].

\subsection{Normal Breast-like}

Approximately $5-10 \%$ of all breast carcinomas are normal breast-like tumors. Since the expression of ER, PR, and HER2 are lacking in normal breast-like tumors, these can be classified as triple-negative and different from basal-like as they are CK5 and EGFR negativity $[18,26]$. The subtypes of breast cancer and its details are given in Table 1. 
Table 1. Details of subtypes of breast cancer.

\begin{tabular}{|c|c|c|c|c|c|}
\hline Subtypes & Status of ER, PR \& HER2 & Originating Cell & Features of IHC & $\begin{array}{l}\text { Percentage of } \\
\text { Occurrence }\end{array}$ & References \\
\hline Luminal A & ER+ or PR+ or Both, HER2- & Luminal Epithelial cell & Keratin $8 / 18$ Positive & $50-60 \%$ & {$[20]$} \\
\hline Luminal B & ER+ or PR+ or Both, HER2+ & Luminal Epithelial cell & Keratin $8 / 18$ Positive & $15-20 \%$ & {$[20,24]$} \\
\hline Basal like & ER- or PR- or HER2 \pm & $\begin{array}{c}\text { Basal or Biopotent } \\
\text { progenitor/myoepithelial cell }\end{array}$ & $\begin{array}{l}\text { Keratin } 5617 \text { positive, } \\
\text { EGFR positive }\end{array}$ & $8-37 \%$ & {$[20,24]$} \\
\hline HER2+ & ER-, PR-, HER2+ & Late luminal progenitor & 一 & $15-25 \%$ & {$[20,24]$} \\
\hline Normal breast like & $\begin{array}{l}\text { Tumors do not fit into any of } \\
\text { these categories }\end{array}$ & Luminal Epithelial cell & 一 & $5-10 \%$ & {$[20,24]$} \\
\hline
\end{tabular}

\section{Pathways Involved in Breast Cancer}

The Akt pathway, downregulated in various cancers, is a key regulator of cell multiplication and survival. Breast cancer tissue microarrays analysis showed that the Akt pathway is activated in the ductal carcinoma in situ (DCIS) stage, which also refers to stage 0 breast cancer [27]. Metformin decreases Akt activation by activating Adenosine $5^{\prime}$-monophosphate-activated protein kinase (AMPK), which leads to increased phosphorylation of IRS-1 at Ser $^{789}$ [28].

The invasive and metastatic phenotype of tumor cells is determined by the overall activity of the cofilin pathway. Cofilin, a small ubiquitous protein, which is approximately $19 \mathrm{kDa}$, is found in invasive mammary tumor cells. The downregulation of cofilin is observed in breast cancer patients and also in individuals with mutations in the BRCA 1 tumor-suppressor gene [29].

The abnormal activation of the Hedgehog (Hh) signaling pathway is distinctly tied to cancer development and progression in a variety of solid malignancies. Hh ligand overexpression is associated with the basal-like subtype of breast cancer phenotype [30]. The Hh pathway plays an essential role in embryonic patterning, and it is also involved in stem cell renewal, tissue regeneration and repair. Three secreted ligands are involved in signaling cascade-sonic Hedgehog (SHH), Indian Hedgehog (IHH), and Desert Hedgehog (DHH). The Hh pathway activation enhances the proliferation invasion and migration of TNBC cells [31]. A steroidal alkaloid, cyclopamine blocks the Hh pathway, suppresses Gli1 expression, and thereby inhibits breast carcinoma cell growth [32]. It is also reported that the Hh pathway mediates the progression from DCIS to invasive ductal carcinoma (IDC) and the Gli1 nuclear translocation ratio could be used as a biomarker for evaluating the ability of invasiveness [33].

Nuclear factor- $\mathrm{kB}(\mathrm{NF} \mathrm{kB})$ belongs to the family of ubiquitously expressed transcription factors is required for normal mammary gland development. NFKB is associated with the progress of ER-negative breast cancer. Clinical evidence reveals that the DNA-binding by p50 subunit of NFKB can be used as a prognostic marker for identifying a high-risk subset of ER-positive [34]. NFKB activity was inhibited by parthenolide (PTL), pyrrolidinedithiocarbamate (PDTC), and its analog diethyldithiocarbamate (DETC) in MCF7 sphere cells [35]. A natural isoflavonoid, Genistein, found in soybean products regulates the expression of genes that prompt apoptosis in breast cancer cells. The inactivation of NFKB by Genistein in MDA-MB-231 cancer cells is partially mediated through the Akt pathway [36].

The genetic and genomic studies have revealed new paths that are activated in various breast cancers, in which somatic mutations occur due to the gain or loss of key genes within the phosphoinositide 3-kinase pathway (PI3K) [37]. PI3K pathway was reported to have alterations in many cases of breast cancers and leads to therapeutic resistance. It is also reported that more than $70 \%$ of breast cancers have a modification in at least in one component of the PI3K pathway, which might be exploited to therapeutic advantage in "basal-like" cancers [38]. One of the most frequent oncogenic aberrations of TNBC is the dysregulation of signaling through the PI3K and Akt signaling pathways [39]. 
PIK3CA mutations and Akt activation by phosphorylation (pAkt) are commonly detected in various cancers, but its frequency is found to be high in breast cancer [40]. The preclinical and neoadjuvant trial data suggested that a PIK3CA alteration showed tolerance to HER2-targeted therapy. The validation of these alterations has treatment modalities towards further advancement of precision medicine for breast cancer [41]. The activation of the PI3K-Akt pathway through the loss of PTEN or PIK3CA mutation was frequently observed in trastuzumab-refractory human breast cancers [42].

PI3K-Akt-mTOR signaling pathway plays a significant role in cancer development because it is involved in regulation of cell growth and survival, apoptosis, motility, cell cycle, and various metabolic functions [43]. The mechanisms involved in activation of a PI3KAkt are constitutively activated receptor tyrosine kinases (IGF/IGFR, ErbB, FGF/FGFR systems) leading to constitutive activation of PI3K; phosphatase and tensin homolog (PTEN) gene function, PI3K mutations: aberrant activation of Akt, eIF4E, 4E-BP1, and p70S6K, where these alterations trigger a cascade of biological events, i.e., from cell growth and proliferation to survival and migration, which contribute to tumor progression. Thus, this pathway is considered a target for the development of novel anticancer molecules [44]. In addition, alterations in the genes encoding several nodes of the PI3K-Akt-mTOR pathway is frequently found in ER-positive breast cancer, which includes activating mutations in the genes encoding IGF-1R and InsR, p110 $\alpha$ PI3K, PDK1, HER2, and Akt1, and loss of expression of genes encoding PTEN [45].

The Wnt pathways have not only been generated in the context of cancer development but also in cancer pathogenesis and, thus, redefining cancer as a result of dysregulation of the developmental process. The types of Wnt pathway are canonical pathway and non-canonical pathway [46]. Wnt antagonists like APC, SFRP1/2, CDH1, and activator $\beta$-catenin (CTNNB1), along with the increased nuclear accumulation of $\beta$-catenin, played a crucial role in the prognosis of breast cancer and had significant clinical as well as prognostic importance [47]. Furthermore, TamR cells exhibited increased Wnt signaling when measured through TOP/FOP Wnt luciferase reporter assays. Genes associated with $\beta$-catenin dependent (AXIN2, MYC, CSNK1A1) and independent arms (ROR2, JUN) as well as Wnt secretion (PORCN) of the Wnt signaling pathway, were upregulated in TamR cells [48].

\section{Breast Cancer Brain Metastasis}

In recent years, the incidence of deaths due to breast cancer brain metastasis (BCBM) has increased. $\alpha \mathrm{B}$-crystallin gene (CRYAB), a molecular chaperone, was reported as the strongest independent predictor of BCBM, and it could be used as a biomarker to identify the patients with a high risk of breast cancer for early relapse in the brain [49]. The subpopulation of the cells that are present in BCBM circulating tumor cells can be used as a biomarker and also for making decisions about the treatment [50].

The breast cancer cell lines are attracted through chemokines CXCL16 and CXCL12 by fibroblasts that are associated with BCBM and therefore, blocking receptor-ligand interaction of CXCR6-CXCL16/CXCR4-CXCL12, which may be preventive therapy for BCBM [51]. Four miRNAs, miR-199A-5p, miR-132-3p, miR-155-5p and miR-150-5p, which were expressed between breast cancer that did not relapse (BCNR) vs. primaries that relapse (BCR) and primaries that relapse (BCR) vs. brain metastasis (BM), can be used to predict the survival of a patient with BCBM [52]. A major complication of breast cancer is blood-borne metastasis to the brain. The proliferation in the brain is caused due to increased Hypoxia Inducible Factor 1A (HIF1A)-associated signaling. Thus, the therapeutic implication may be used for the activation of hypoxic signaling [53]. Recent research hypothesized that nephronectin, an extracellular matrix protein promotes BCBM via integrin $(\alpha 8 \beta 1)$ binding motifs [54]. The BCBM is promoted by the interaction of astrocytes in the brain and the invading triple-negative breast cancer cells via TGF- $\beta 2$ (Transforming Growth Factor-beta-2) produced by astrocytes and is responsible for ANGPTL4 expression upregulation/angiopoietin-like 4 (ANGPTL4) [55]. The epithelial-to-mesenchymal transi- 
tion, invasion, and BCM are inhibited by the GATA3-UTX-Dicer axis, where GATA3, a type of transcription factor, is positively correlated with a histone H3K27 demethylase, UTX [56]. The various mechanism of different genes or molecules and their role are mentioned in Table 2.

Table 2. Various mechanism of genes or molecules and its role.

\begin{tabular}{|c|c|c|c|}
\hline Genes or Molecules & Mechanism & Role & References \\
\hline$\alpha \mathrm{B}$-crystallin Gene & $\begin{array}{l}\text { Intracrine VEGF signaling and implicate } \\
\text { UPR/CRYAB as dichotomous parts of } \\
\text { regulation pathway }\end{array}$ & Biomarker & [49] \\
\hline Subpopulation of BCBM CTCs & $\begin{array}{l}\text { Inhibition of EIF2, IGF-, ILK, VEGF and } \\
\text { Integrin signaling }\end{array}$ & Biomarker & [50] \\
\hline Cancer-associated Fibroblasts & $\begin{array}{l}\text { Chemokines CXCL16 and CXCX12 by } \\
\text { fibroblasts and blocks the interaction of } \\
\text { CXCR6-CXCL6/CXCR4-CXCL12 }\end{array}$ & Preventive therapy for BCBM & {$[51]$} \\
\hline $\begin{array}{l}\text { miR-132-3p, miR-199A-5p, } \\
\text { miR-150-5p and miR-155-5p }\end{array}$ & cMET-targeting & $\begin{array}{c}\text { Predict the survival rate of patients and } \\
\text { biomarker }\end{array}$ & [52] \\
\hline Circulating Tumour Cells (CTCs) & $\begin{array}{l}\text { Hypoxia Inducible Factor 1A-assocated } \\
\text { signaling }\end{array}$ & Therapeutic implication & [53] \\
\hline Nephronectin & Promotes BCBM via $\alpha \beta 1$-binding motif & $\begin{array}{l}\text { Reduced endothelial adhesion and } \\
\text { transmigration }\end{array}$ & [54] \\
\hline $\begin{array}{c}\text { Interaction of astrocytes and invading } \\
\text { TNBC cells }\end{array}$ & TGF- $\beta 2 /$ ANGPTL 4 axis & $\begin{array}{c}\text { Promoting BCBM and ANGTL4 for } \\
\text { treatment of BCBM }\end{array}$ & [55] \\
\hline GATA3-UTX-Dicer axis & $\begin{array}{l}\text { GATA3 expression is positively correlated with } \\
\text { UTX, histone H3K27 demethylase }\end{array}$ & $\begin{array}{l}\text { Epithelial-to-mesenchymal transition, } \\
\text { invasion and BCM inhibition }\end{array}$ & [56] \\
\hline
\end{tabular}

\section{Chemoresistivity}

Recent studies revealed that nitrogen had the efficiency to block tumor metastasis of TNBC by promoting mesenchymal to epithelial transformation in MDA-MB-231-Luciferase cells [57]. TXX-1-10, a derivative of rimonabant, reduced expression of HPIP and has an inhibitory effect on breast cancer growth and metastasis [58]. Trifluoperazine hydrochloride, an antipsychotic drug, is administered to suppress the growth of TNBC and brain metastasis by inducing apoptosis and G0/G1 arrest via reducing the cyclin D1/CDK4 and cyclin E/CDK2 expressions in MDA-MB-486, MDA-MB-231, and 4T1 cancer cell lines [59]. A transcription suppressor and a significant proto-oncogene, the factor that binds to the inducer of short transcript-1 (FBI-1) increased the expression of PXR by inhibiting miR30c expression [60]. Thus, FBI-1 mediates drug resistance of TNBC cells through miR30c/PXR axis. The zinc finger E-box binding homeobox 1 (ZEB1) expression showed a positive correlation with the expression of Bcl-xL and cyclin D1 [61]. Additionally, the ataxia-telangiectasia mutated (ATM) was transcriptionally activated by ZEB1 and formed ZEB1/p300/PCAF complex, which mediates DNA damage repair and clearance of DNA breaks. It showed that ZEB1 was a determinant of chemoresistance in breast cancer [61]. Cell cycle-related E3 ubiquitin ligase checkpoint with fork-head and ring finger domains (CHFR) plays a major role in the negative regulation of ZEB1. It has been inferred that CHFR-ZEB1 signaling acted as chemo resistive in malignant breast cancers [62]. The synergistic effect of melatonin and doxorubicin induces apoptosis by decreasing AMPactivated protein kinase $\alpha 1$ (AMPK $\alpha 1$ ) expression at the transcriptional level through an autophagy-dependent mechanism [63]. An actin-bundling protein fascin increased chemoresistance through P13K/Akt signaling and suppressed pro-apoptotic markers such as caspase 9, caspase 3, and PARP, which resulted in regulation of breast cancer metastasis and survival [64]. Luteinizing Hormone-Releasing Hormone (LHRH) is conjugated with prodigiosin (PGS) and paclitaxel (PTX) inhibited the growth of TNBC in in vitro and in vivo experiments [65]. The mechanism of various types of drugs/genes are shown in Table 3. 
Table 3. Drug/gene and its mechanism.

\begin{tabular}{|c|c|c|}
\hline Drug/Gene & Mechanism & References \\
\hline Nitrofen & Mesenchymal-to-epithelial transformation & [57] \\
\hline TXX-1-10 & Reduced the expression of HPIP & [58] \\
\hline Trifluoperazine hydrochloride & $\begin{array}{c}\text { Induce apoptosis and G0/G1 cell arrest by } \\
\text { decreasing cyclin D1/CDK4 and cyclin E/CDK2 } \\
\text { expression }\end{array}$ & [59] \\
\hline FBI-1 & $\begin{array}{l}\text { Drug resistance of TNBC cells through } \\
\text { miR-30c/PXR axis }\end{array}$ & {$[60]$} \\
\hline \multirow{2}{*}{ ZEB1 } & $\begin{array}{l}\text { ZEB1/p300/PCAF complex which mediates } \\
\text { clearance of DNA breaks and DNA damage repair }\end{array}$ & {$[61]$} \\
\hline & CHFR plays a major role in negative regulation & {$[62]$} \\
\hline Synergistic effect of melatonin and doxorubicin & $\begin{array}{l}\text { Apoptosis induction by }(\mathrm{AMPK} \alpha 1) \text { at } \\
\text { transcription level }\end{array}$ & {$[63]$} \\
\hline Fascin & $\begin{array}{l}\text { Chemoresistance through P13K/Akt signaling and } \\
\text { suppressed proapoptotic markers }\end{array}$ & {$[64]$} \\
\hline LHRH conjugation of PGS and PTX & Inhibition of TNBC growth & {$[65]$} \\
\hline
\end{tabular}

\section{Anticancer Activity of Medicinal Plants}

Phytochemicals can be used as chemotherapeutics that are isolated from various plant extracts as these phytochemicals have shown diverse effects on anti-tumor, antiinflammation, anti-oxidant, and anti-bacterial [66]. Phytochemicals such as vinca alkaloids, taxanes, Camptothecin derivatives, Cephalotaxus, Colchicine, Ellipticine, Berberine, Combretastatins, and triterpenoid acids showed the anticancer activity against various cancer types [67]. Plants also have positive results in curing diabetes, sterility, thyroid, fertility, and physiological disorders [68].

\subsection{Echinacea}

Echinacea belongs to the family Asteraceae. E. purpurea, E. angustifolia, E. pallida are the most commonly used species. E. purpurea is most commonly used in cancer treatment. It is commonly known as coneflower. It increases the number of Natural Killer Cells (NKCs), and the flavonoids act as an immune stimulant [69]. The crude extracts of root and leaf of E. purpurea possess $\mathrm{IC}_{50}$ values of $350 \mu \mathrm{g} / \mathrm{mL}$ and $280 \mu \mathrm{g} / \mathrm{mL}$ against BT-549 cell lines [70]. E. angustifolia DC extract was obtained with ethyl acetate $(E a-A c O E t)$. When this extract was quantified with HPLC, echinacoside and caffeic acid content was assessed and its cytotoxicity against MDA-MB-231 and MCF-7 cells were found to be $28.18 \pm 1.14 \mu \mathrm{g} / \mathrm{mL}$ and $19.97 \pm 2.31 \mu \mathrm{g} / \mathrm{mL}$, respectively. In addition, Ea-AcOEt showed a synergistic effect with paclitaxel [71].

\subsection{Allium sativum}

Allium sativum is commonly known as garlic. Allicin, the originator of the sulfurcontaining compound, is responsible for therapeutic properties. Another sulfur-holding substance called Ajoene delays the development of cancer. Selenium acts as an antioxidant. Ripened extract of garlic helps in shielding the propagation of cancers [72]. Ajoene restrained the growth of human breast cancer cells [73]. A. sativum exhibits anticancer activity against MCF-7 breast cancer cells when encapsulated with silver nanoparticles and had showed an $\mathrm{IC}_{50}$ value of $89.86 \mu \mathrm{g} / \mathrm{mL}$ [74].

\subsection{Curcuma longa}

Curcuma longa, which is commonly known as turmeric, has an ingredient called curcumin, which has anticancer activity due to the presence of phenolic substances [75]. 
Curcumin-loaded nanoparticles have low toxicity and anti-inflammatory effect. It induced the inhibition of NFkB, AP-1, and STAT3 transcription factors and it also arrested cell cycle in the G2/M phase [76]. Further, pulsed electric field (PEF) treated C. longa showed effective inhibition against MCF-7 breast cancer cell line, and this could be an alternative method to treat cancer with minimal side effects [77]. The ethanolic extract of $C$. longa had $\mathrm{IC}_{50}$ values of $49 \pm 2.08 \mu \mathrm{g} / \mathrm{mL}$ in $0.25 \%$ DMSO and $40 \pm 1.03 \mu \mathrm{g} / \mathrm{mL}$ in $0.5 \%$ DMSO against MDA-MB-231 cell line [78].

\subsection{Arctium lappa}

Arctium lappa is commonly known as Burdock. Its seeds contain Arctigenin, which is one of the potential anti-cancerous compounds and it can eliminate tumor cells and their formation [79]. Lappaol F, an anticancer agent which has been isolated from Arctium lappa L. has arrested the G2 cell cycle by inducing the G1 phase. p21 plays a vital role in G2 arrest by lappaol F-mediated regulation of CDK1 and cyclin B1 [80]. The synergetic effect of A. lappa root extract and doxorubicin showed apoptotic effect and antiproliferative effect against MCF-7 and MDA-MB-231 cell lines [81]. It also exhibits an $\mathrm{IC}_{50}$ value of $41.5 \mu \mathrm{mol} / \mathrm{L}$ for the MDA-MB-231 cell line [82].

\subsection{Synadenium cupulare}

Synadenium cupulare leaf water extract was used for the synthesis of $\mathrm{CdO} / \mathrm{CdO}_{3}$ nanocomposite using cadmium nitrate tetrahydrate. Tannins, saponins, flavonoids and glycosides were present in the leaf extract which showed anti-cancer properties. The $\mathrm{IC}_{50}$ values of various extracts are shown in Table 4 [83].

\subsection{Cimicifuga foetida}

Cimicifuga foetida is commonly known as black cohosh. Actein, a triterpene glycoside inhibits Ras/MEK/ERK signaling pathway and Akt phosphorylation in MCF-7 cells and suppresses TNF $\alpha$-induced IKK $\alpha / \beta$ and IKK $\alpha$ phosphorylation, as well as NFKB downstream targeting gene expression in TNBC [84]. A cycloartane triterpenoid, KHF16 which was isolated from rhizomes of $C$. foetida induced G2/M phase arrest and apoptosis in MDAMB-468 and possess $\mathrm{IC}_{50}$ of $5.6 \mu \mathrm{M}, 6.8 \mu \mathrm{M}$, and $9.2 \mu \mathrm{M}$ against MCF-7, MDA-MB-231, and MDA-MB-468 cell lines, respectively [85].

\subsection{Cymbopogon citratus}

Cymbopogon citratus is a citrus-based plant, which contains citral. Nanostructured Lipid Carrier-citral showed better results than citral itself when treated in MDA-MB231 breast cancer cells [86]. Essential oil of $C$. citratus showed anticancer effect on 7, 12-Dimethylbenz- $[\alpha]$-anthracene (DMBA)-induced breast cancer in female rats with $\mathrm{IC}_{50}$ values of $12.03 \mu \mathrm{g} / \mathrm{mL}$ [87]. Furthermore, polysaccharide fractions of C. citratus showed cytotoxic and apoptotic effects by upregulating caspase3, downregulating bcl-2 genes followed by the release of cytochrome C [88].

\subsection{Zingiber officinale}

Zingiber officinale is commonly kwon as Ginger and is widely used for the treatment of cancer [89]. The extracts of $Z$. officinale possess significant antiproliferative activity against TNBC [90]. In addition, Z. officinale suppresses MCF-7 and MDA-MB-231 cell lines proliferation and colony formation by upregulating Bax and downregulating $\mathrm{Bcl} 2$ proteins. It also downregulates the expression of NF- $\mathrm{kB}, \mathrm{Bcl}-\mathrm{X}, \mathrm{Mcl}-1$ and Survivin, cyclin D1, and CDK-4 [91]. Fulbaria and Syedpuri, the two Bangladeshi ginger varieties and showed anticancer activity in MCF-7 and MDA-MB-231 cell lines with IC 50 values of 34.8 and $25.7 \mu \mathrm{g} / \mathrm{mL}$ for Fulbaria. MDA-MB-231 exhibition were 32.53 and $30.20 \mu \mathrm{g} / \mathrm{mL}$ for rhizomes extract of Fulbaria and Syedpuri [92]. 


\subsection{Rhus coriaria}

Rhus coriaria, known as Sumac, contains phenolic acids, flavonoids, and tannins [93]. It suppresses the metastasis of breast cancer by inhibiting STAT3, $\mathrm{NK} \kappa \mathrm{B}$, and $\mathrm{NO}$ pathways. $R$. coriaria ethanolic extract (RCE) inhibits cell proliferation by cell cycle arrest at the G1 phase and senescence [94]. R. coriaria was evinced to be a promising therapeutic drug against breast cancer as it induced senescence and autophagy cell death by the activation of p38 and ERK1/2 [95]. RCE also upregulates p21, downregulates cyclin D1, c-myc, PCNA, p27, phosphor-RB, and senescence-associated $\beta$-galactosidase expressions in T47D, MCF-7, and MDA-MB-231 cell lines. MDA-MB-231 cell lines showed an IC $_{50}$ value of $215 \mu \mathrm{g} / \mathrm{mL}$ whereas MCF-7 cell lines showed $155 \mu \mathrm{g} / \mathrm{mL}$ [96].

\subsection{Ricinus communis $\mathrm{L}$.}

Ricinus communis L. fruit extract showed antiproliferative activity on MCF-7, MDAMB-231. It contains various medicinally important compounds such as Ricinine, $\mathrm{p}$ coumaric acid, Epigallocatechin, and Ricinoleic acid [97]. The phytochemicals present in $R$. communis target peroxisome proliferator-activated receptor (PPAR), NF- $\mathrm{KB}$, cytochrome p450, p38 MAPK, p53, and Bcl-xL [98]. The seed of R. communis has been encapsulated with zinc oxide nanoparticles and it was reported that $\mathrm{IC}_{50}$ against MDA-MB-231 cells was $7.103 \mu \mathrm{g} / \mathrm{mL}$ [99].

\subsection{Drosera bormannii}

Drosera bormannii, commonly known as the Sundew plant, has anti-inflammatory and anti-cancer activity. It arrests the cell cycle at the G2/M phase and induces apoptosis in MCF-7 cells. It also upregulates the p53 and $\mathrm{Bax} / \mathrm{Bcl}$ ratio. Compounds present in D. bormannii includes hexadecenoic acid, tetradecanoic acid, hexadecen-1-ol, trans-9 and 1-tetradecanol, and other fatty acids. The $\mathrm{IC}_{50}$ value was found to be $120.94 \pm 1.91 \mu \mathrm{g} / \mathrm{mL}$ when MCF-7 cells have been treated with methanolic extract of Drosera bormannii [100].

\subsection{Acacia hydasica}

Acacia hydasica R. parker contains four active phenolic compounds namely catechin, 7-O-galloyl catechin, catechin-3-O-gallate (CG), methyl gallate (MG). MDA-MB-231 breast cancer cell growth was inhibited by MG and CG. It also induced the reduction of CK2 $\alpha$, $\mathrm{Bcl}-\mathrm{XL}$, surviving, and xIAP protein expression through the suppression of the JAK/STAT pathway, $\mathrm{NK \kappa B}$, and p13K pathway [101].

\subsection{Saussurea lappa}

Saussurea lappa root contains two natural sesquiterpene lactones namely costunolide (cos) and dehydrocostuslactone (Dehy). The apoptotic activity of breast cancer is inhibited through AKT/14-3-3 and c-Myc/p53 pathway [102]. The dried roots of S. lappa contain sesquiterpene lactone that acts as an anti-tumor agent against the MCF-7 cell line with an $\mathrm{IC}_{50}$ value of $35.05 \pm 9.37 \mu \mathrm{g} / \mathrm{mL}$ [103]. Saussurea lappa Clarke (SLC) and its derivative costunolide have been reported to suppress MDA-MB-231 cell growth and metastasis by inhibiting TNF $\alpha$-induced NF- $\mathrm{kB}$ activation [104].

\subsection{Centella asiatica}

Centella asiatica possess anticancer activity against MCF-7 cell lines [105]. It contains Asiatic acid which inhibits WAWE3 expression and activation through the P13K/Akt pathway-invasion and proliferation of MDA-MB-231 cells [106]. Aqueous extract of C. asiatica have exhibited the $\mathrm{IC}_{50}$ of $648.00 \mu \mathrm{g} / \mathrm{mL}$ against MDA-MB-231 cell lines [107].

\subsection{Eclipta alba}

Wedelolactone, a compound present in Eclipta alba inhibits MCF-7, T47D, and MDAMB-231 cells by stimulating ER signaling [108]. Chloroform fractionization of E. alba leaves disrupts the mitochondrial membrane potential, upregulates Hsp60, and downregulates 
the expression of anti-apoptotic protein XIAP as it activates an apoptotic pathway in MCF-7, MDA-MB-231. The $\mathrm{IC}_{50}$ values were found to be $18.03 \pm 2.0 \mu \mathrm{g} / \mathrm{mL}$ and $42.5 \pm 3.5 \mu \mathrm{g} / \mathrm{mL}$ against both cell lines [109]. The list of medicinal plants and their extract/compound that acts on various cell lines with their $\mathrm{IC}_{50}$ values are summarized in Table 4 .

Table 4. Medicinal plants and its extract/compound that acts on various cell lines with its $\mathrm{IC}_{50}$ values.

\begin{tabular}{|c|c|c|c|c|c|}
\hline Plant & Structure & Extract/Compound & Cell Lines & $\mathrm{IC}_{50}$ & References \\
\hline \multirow{4}{*}{ Echinacea purpurea } & & Crude extract of root & BT-549 & $350 \mu \mathrm{g} / \mathrm{mL}$ & \multirow{4}{*}[70,110]{} \\
\hline & & & & & \\
\hline & & Leaf extract & BT-549 & $280 \mu \mathrm{g} / \mathrm{mL}$ & \\
\hline & icoric aci & & & & \\
\hline
\end{tabular}

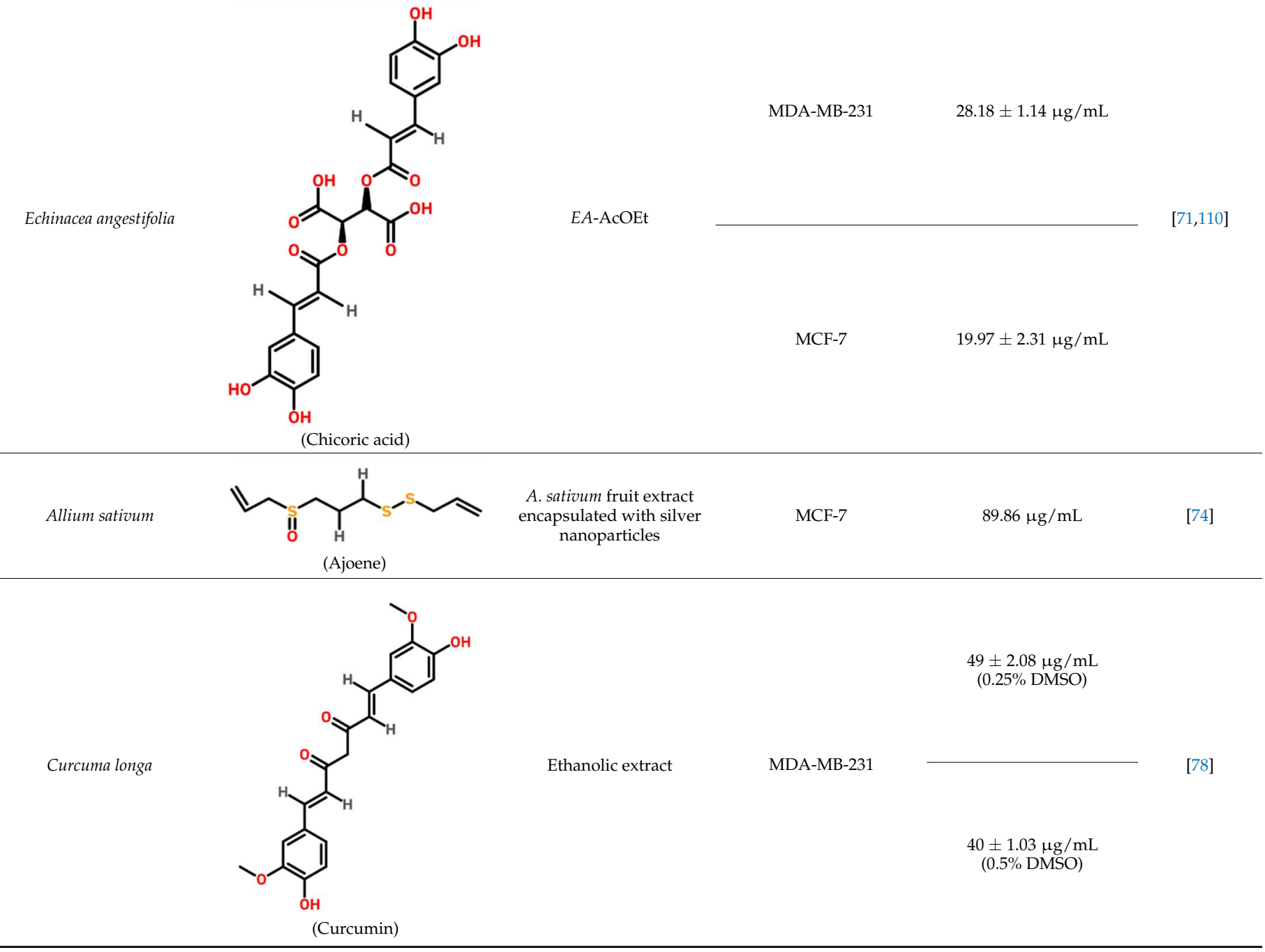


Table 4. Cont.

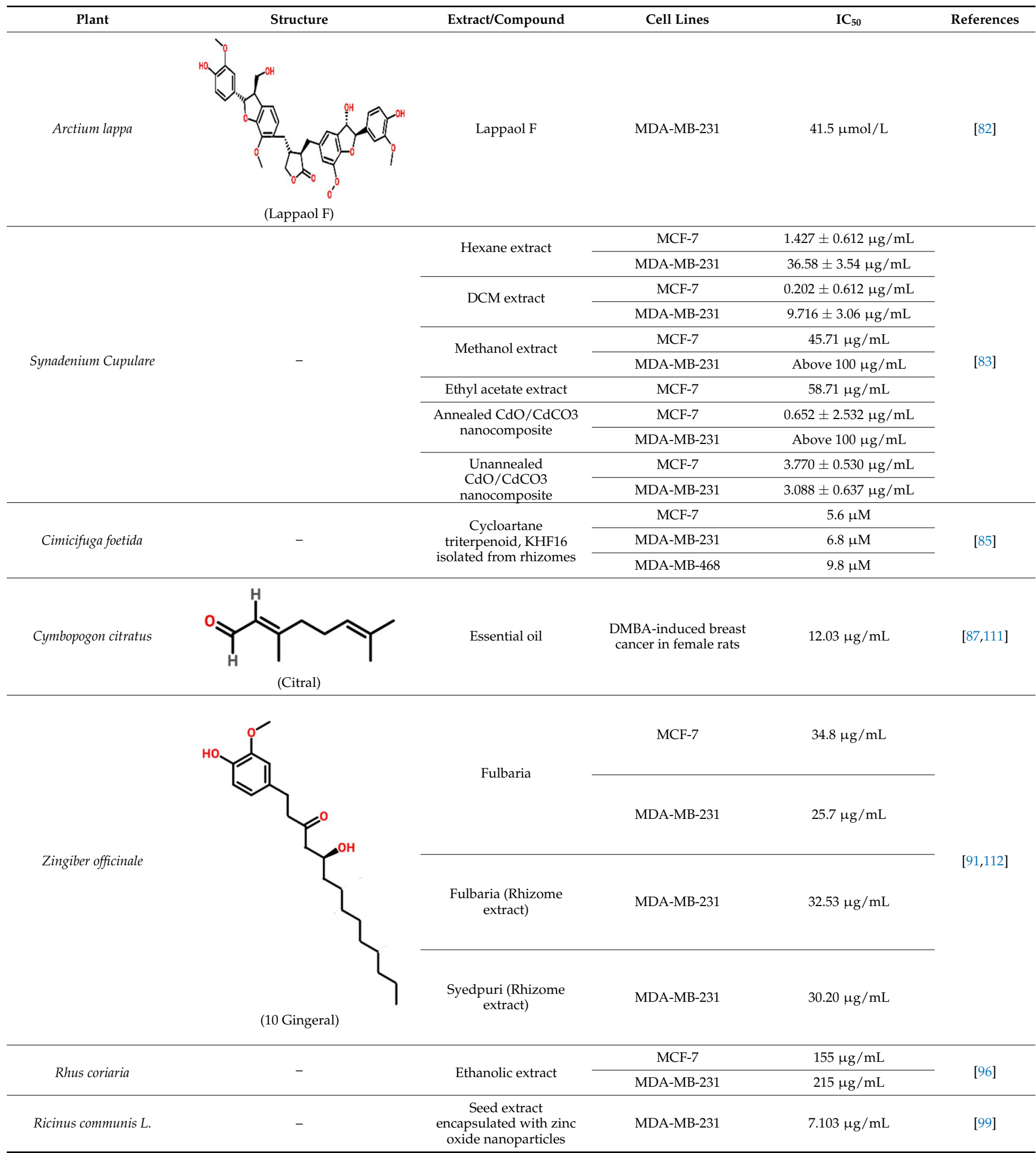


Table 4. Cont.

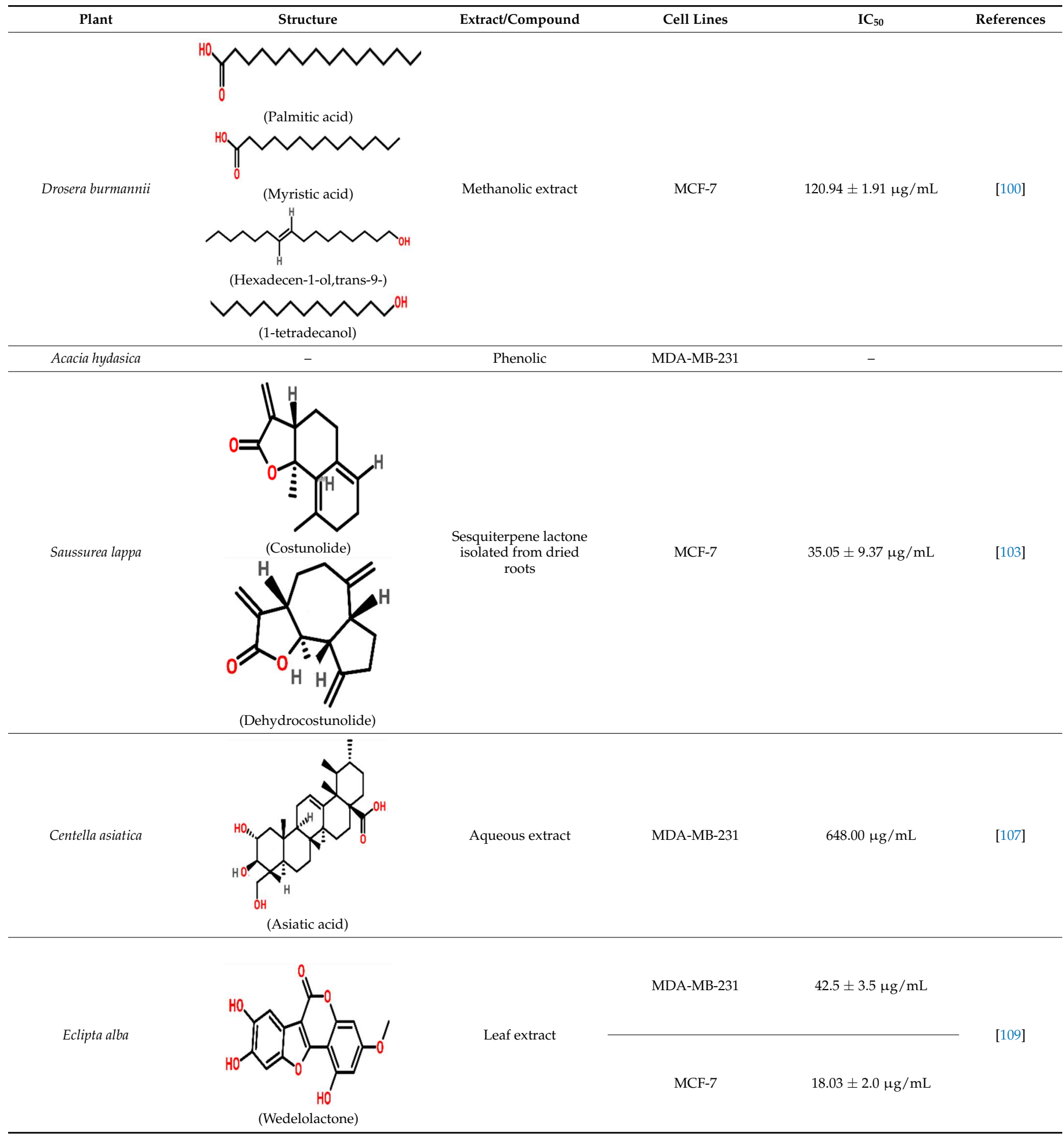

\section{Bioinformatics Approaches}

\subsection{Systems Pharmacology}

One of the most prominent emerging tools to study the interactions between drugs and biological systems is systems pharmacology [113]. Systems pharmacology, also known as network pharmacology, can be used to find the predictive targets, protein-to-protein interaction networks, and signaling pathways in drug treating diseases [114]. In recent years, various natural products were identified using systems pharmacology along with 
their mechanisms [115]. Subsequently, network biology also plays an important role in the identification of significant genes associated with various diseases.

Recent studies revealed that the systems pharmacology approach identified wogonoside as an effective angiogenesis inhibition in TNBC [116]. A systems pharmacology approach was employed between the major compounds of Iranian Chrysanthemum cultivars and known breast cancer drugs with breast cancer-related targets to analyze the mechanism. Among the major compounds of these cultivars, rutin has shown anticancer activity against MCF-7 cell line [117]. The systems pharmacology approach gives an idea of the target compound network as well as the signaling pathways associated with treating complex diseases like breast cancer apart from the confirmation study of the chosen target [118].

Quantitative systems pharmacology (QSP) bridges systems biology with pharmacokinetics (PK) and pharmacodynamics (PD), which gives a maximum understanding of the drug's efficacy and toxicity in complex disease systems like breast cancer [119]. Recent research demonstrates the possibility of combining single-cell data to initialize cell states in special quantitative systems pharmacology (SPQSP) for the prediction of TNBC immunotherapy response [120].

Immune oncology also known as cancer immunotherapy is a form of cancer treatment that directs the patient's own immune system to fight against cancer. Recently developed QSP modes will be increasing by use in IO drug development, which will become IO practice to run virtual trials along with critical trials on the other hand. This can quickly bring better therapeutics to cancer patients [121].

\subsection{Cheminformatics}

The substantial growth in epigenetics-related data in recent years has led to the development of cheminformatics methods. Hidden allosteric binding sites and proteinprotein interaction hotspots for epigenetic targets could be found using computational approaches. In addition, molecular modeling and cheminformatics have made significant contributions to drug discovery [122]. Quantitative structure-activity relationship (QSAR) is also one of the most important methods used for drug discovery. This employs a multi-target approach that can be used to predict anti-cancer agents against various cell lines simultaneously.

Cheminformatics-based selection of small molecules binary weapons that improve transporter-mediated targeting helps in enhancing drug efficacy and therapeutic index [123]. Cheminformatic approaches along with web ontology language can be used for exploring the pharmacogenomics knowledge base for repositioning breast cancer drugs, which gives better performance of new indications and possible conflicting effects prediction for breast cancer drugs. Drug repurposing is one of the most efficient approaches to speed up the drug discovery process by finding new therapeutic uses from existing drugs [124]. The important criteria for repurposing it is to understand and identify the relationship between diseases and drugs, which can be achieved with the help of cheminformatic approaches. Computational approaches that use cheminformatics and molecular modeling methods have been reported to speed up natural product-based drug discovery. Organization, analysis, and dissemination of chemical information of the natural products in compound databases are some of the applications of cheminformatics. Other applications are computer-aided natural product selection, identification of molecular targets for natural products, de novo design, and quantification of natural product likeliness [125].

\section{Recent Trends in Indigenous Medicinal Plant Informatics and Avenues to Combat Cancer}

With the advent of bioinformatics, information technology and omics, there is an everincreasing trend to build resources and knowledgebases that reports herbal formulations, bio-active compounds of the medicinal plants and related information. There are several efforts such as Indian Medicinal Plants, Phytochemistry And Therapeutics (IMPPAT) [126], SymMap [127], Indian medicinal plants database (IMPLAD) [128], Collective Molecular 
Activities of Useful Plants (CMAUP) [129], etc. Furthermore, researchers have developed the novel strategies for in silico based pharmacokinetic properties of drugs/bioactive molecules [130-134]. These approaches are also applicable foe phytochemicals and plant bioactive molecules for their virtual screening, plausible and possible mode of mechanism and drug discovery [135]. Many plant-based anti-cancerous bioactive molecules have been evaluated via computational biology and systems pharmacology tools [136-138]. This review encourages further research on anticancer notably breast cancer active molecules for their bioinformatic screening and pharmacokinetic activities. Considering these facts, the plant derived bio-actives based drug formulations usually consist of many phytocompounds or even more than one particular plant. The main task on this path would be able to impute the role of phytochemicals other than active molecules and which are present in the traditional medicine.

\section{Bioactive Compounds and Their Future Perspectives:}

Medicinal plants contain several bioactive compounds that can be curative for various diseases, including cancer [139]. There are various traditional treatment methodologies in the world among which Ayurveda is the most commonly followed system in India. Some of the traditionally used plants against cancer in India includes Nichinda (Vitex trifolia), Indian Ipecac (Tylopora indica), Arjuna Bark (Terminalia arjuna), and other plants as previously mentioned in this review. These ethnobotanical resources can be used as natural alternatives because of their biomedical properties [140]. The secondary metabolites present in the plants are used for the production of drugs [141]. Apart from increasing the efficacy of chemo drugs, plant-based bioactive compounds can sometimes cause side effects when administered as chemotherapeutic agents [142]. These bioactive compounds also alter the biological pathways and modulate the immune system, which results in the suppression of breast cancer [143]. The expression of miRNAs can be changed using plant-derived bioactive compounds and thus it can be used as a promising approach for breast cancer treatment [144]. Bioactive compounds like tanshinones, berberine, matrine, and astragaloside IV showed inhibitory effect on breast cancer cells by rescuing miRNA expression [145]. These plants not only prevent or inhibit cancer, but also help in overall improvement of health.

\section{Conclusions and Future Perspectives}

As breast cancer is one of the leading causes of death observed in women, it is necessary to diagnose and treat it in the early stages to prevent metastasis. Since radiotherapy, chemotherapy, and surgery cause side effects, medicinal plants are used as a better alternative for its treatment. This holistic review details the different medicinal plants and their anti-cancerous potential. Not all the medicinal plants completely cure the disease; such plants are synthesizing the active anti-cancerous compounds. These compounds act synergistically with chemotherapeutic drugs to enhance the efficiency of the drug with minimal side effects. This review article also highlights the mechanism of antitumor action of some important native medicinal plants. It is generally done via diverse signaling pathways. These research analyses are notably performed in human cell lines. In addition, bioinformatics tools also play a key role in drug targeting, protein-protein interaction studies, identification of compound target networks, and pathways associated with treating complex diseases like cancer. QSP modes could be used in IO drug development that would help to run virtual trials on one hand and clinical trials on the other hand. This helps in bringing better therapies for cancer patients. In silico approaches are cost-effective and the results will be more precise so that this could be used as a tool to analyze the cancer-related target mechanism and to design drugs with more efficiency. Though, the analyses of these plants should not limit the study of plethora of anticancer medicinal plants, many of which remain unexplored. Further studies are required to highlight the possible or plausible mode of action along with in silico omics approaches of several explored and unexplored medicinal plants. 
Author Contributions: Conceptualization, V.S. and P.M.; writing-original draft, V.S. and S.A.; writing-review and editing, P.M., M.S., J.-T.C., H.S. and M.R. All authors have read and agreed to the published version of the manuscript.

Funding: This research received no external funding.

Conflicts of Interest: Authors have no conflict of interest.

\section{References}

1. Petrovska, B.B. Historical review of medicinal plants' usage. Pharmacogn. Rev. 2012, 6, 1-5. [CrossRef]

2. Cosme, P.; Rodríguez, A.B.; Espino, J.; Garrido, M. Plant phenolics: Bioavailability as a key determinant of their potential health-promoting applications. Antioxidants 2020, 9, 1263. [CrossRef] [PubMed]

3. Linnewiel-Hermoni, K.; Khanin, M.; Danilenko, M.; Zango, G.; Amosi, Y.; Levy, J.; Sharoni, Y. The anti-cancer effects of carotenoids and other phytonutrients resides in their combined activity. Arch. Biochem. Biophys. 2015, 572, 28-35. [CrossRef] [PubMed]

4. Habli, Z.; Toumieh, G.; Fatfat, M.; Rahal, O.N.; Gali-Muhtasib, H. Emerging cytotoxic alkaloids in the battle against cancer: Overview of molecular mechanisms. Molecules 2017, 22, 250. [CrossRef] [PubMed]

5. Nagai, H.; Kim, Y.H. Cancer prevention from the perspective of global cancer burden patterns. J. Thorac. Dis. 2017, 9, 448. [CrossRef] [PubMed]

6. Kondov, B.; Milenkovikj, Z.; Kondov, G.; Petrushevska, G.; Basheska, N.; Bogdanovska-Todorovska, M.; Tolevska, N.; Ivkovski, L. Presentation of the Molecular Subtypes of Breast Cancer Detected by Immunohistochemistry in Surgically Treated Patients. Open Access Maced. J. Med. Sci. 2018, 6, 961-967. [CrossRef]

7. Redig, A.J.; McAllister, S.S. Breast cancer as a systemic disease: A view of metastasis. J. Intern. Med. 2013, 274, 113-126. [CrossRef]

8. Cordero, M.J.A.; Villar, N.M.; Sánchez, M.N.; Pimentel-Ramírez, M.L.; García-Rillo, A.; Valverde, E.G. Breast cancer and body image as a prognostic factor of depression: A case study in México City. Nutr Hosp. 2015, 31, 371-379.

9. Pan, S.Y.; Zhou, S.F.; Gao, S.H.; Yu, Z.L.; Zhang, S.F.; Tang, M.K.; Sun, J.N.; Ma, D.L.; Han, Y.F.; Fong, W.F.; et al. New perspectives on how to discover drugs from herbal medicines: CAM's outstanding contribution to modern therapeutics. Evid. Based Complement. Alternat. Med. 2013, 2013, 5-12. [CrossRef]

10. Laskar, Y.B.; Lourembam, R.M.; Mazumder, P.B. Herbal remedies for breast cancer prevention and treatment. In Medicinal Plants-Use in Prevention and Treatment of Diseases; InTech Open: London, UK, 2020; Chapter 3.

11. Li, Y.; Li, S.; Meng, X.; Gan, R.Y.; Zhang, J.J.; Li, H.B. Dietary Natural Products for Prevention and Treatment of Breast Cancer. Nutrients 2017, 9, 728. [CrossRef]

12. Solowey, E.; Lichtenstein, M.; Sallon, S.; Paavilainen, H.; Solowey, E.; Lorberboum-Galski, H. Evaluating medicinal plants for anticancer activity. Sci. World J. 2014, 2014, 1-12. [CrossRef] [PubMed]

13. Moshiri, M.; Hamid, F.; Etemad, L. Ricin toxicity: Clinical and molecular aspects. Rep. Biochem. Mol. $2016,4,60$.

14. Leitzmann, M.; Powers, H.; Anderson, A.S.; Scoccianti, C.; Berrino, F.; Boutron-Ruault, M.C.; Cecchini, M.; Espina, C.; Key, J.T.; Norat, T.; et al. European code against cancer $4^{\text {th }}$ Edition: Physical activity and cancer. Cancer. Epidemiol. 2015, 39, S46-S55. [CrossRef] [PubMed]

15. Sharma, V.; Sarkar, I.N. Bioinformatics opportunities for identification and study of medicinal plants. Brief. Bioinform. 2013, 14, 238-250. [CrossRef]

16. Cui, Z.J.; Gao, M.; Quan, Y.; Lv, B.M.; Tong, X.Y.; Dai, T.F.; Zhou, X.H.; Zhang, H.Y. Systems Pharmacology-Based Precision Therapy and Drug Combination Discovery for Breast Cancer. Cancers 2021, 13, 3586. [CrossRef]

17. Wishart, D.S. Current Protoc Bioinformatics. Introduction to Cheminformatics; John Wiley \& Sons: Edmonton, AB, Canada, 2007; Volume 14, pp. 1-9.

18. Carey, L.A. Through a glass darkly: Advances in understanding breast cancer biology, 2000-2010. Clin. Breast Cancer 2010, 10, 188-195. [CrossRef]

19. Shao, M.M.; Chan, S.K.; Yu, A.M.; Lam, C.C.; Tsang, J.Y.; Lui, P.C.; Law, B.K.; Tan, P.H.; Tse, G.M. Keratin expression in breast cancers. Virchows Arch. 2012, 461, 313-322. [CrossRef] [PubMed]

20. Yersal, O.; Barutca, S. Biological subtypes of breast cancer: Prognostic and therapeutic implications. World. J. Clin. Oncol. 2014, 5, 412-424. [CrossRef]

21. Jia, R.; Li, Z.; Liang, W. Identification of key genes unique to the luminal a and basal-like breast cancer subtypes via bioinformatic analysis. World. J. Surg. Oncol. 2020, 18, 268. [CrossRef]

22. Rakha, E.A.; Elsheiskh, S.E.; Aleskandarany, M.A.; Habashi, H.O.; Green, A.R.; Powe, D.G.; El-Sayed, M.E.; Benhasouna, A.; Brunet, J.S.; Akslen, L.A.; et al. Triple-negative breast cancer: Distinguish between basal and non-basal subtypes. Clin. Cancer Res. 2009, 15, 2302-2310. [CrossRef]

23. Alluri, P.; Newman, L.A. Basal-like and triple-negative breast cancers: Searching for positives among many negatives. Surg. Oncol. Clin. N. Am. 2014, 23, 567-577. [CrossRef]

24. Kreike, B.; van Kouwenhove, M.; Horlings, H.; Weigelt, B.; Peterse, H.; Bartelink, H.; van de Vijer, M.J. Gene expression profiling and histopathological characterization of triple-negative/basal-like breast carcinomas. Breast Cancer Res. 2007, 9, 65. [CrossRef]

25. Kumar, P.; Aggarwal, R. An overview of triple-negative breast cancer. Arch. Gynecol. Obset. 2016, 15, 3859. [CrossRef]

26. Schettini, F.; Prat, A. Dissecting the biological heterogeneity of HER2-positive breast cancer. Breast 2021, 59, 339-350. [CrossRef] 
27. Yin, L.; Duan, J.J.; Bian, X.W.; Yi, S.C. Triple-negative breast cancer molecular subtyping and treatment progress. Breast Cancer Res. 2020, 22, 61. [CrossRef] [PubMed]

28. Bose, S.; Chandran, S.; Mirocha, J.; Bose, N. The Akt pathway in human breast cancer: A tissue-array-based analysis. Mod. Pathol. 2006, 19, 238-245. [CrossRef] [PubMed]

29. Zakikhani, M.; Blouin, M.J.; Piura, E.; Pollak, M.N. Metformin and rapamycin have distinct effects on the AKT pathway and proliferation in breast cancer cells. Breast Cancer Res. Treat. 2010, 123, 271-279. [CrossRef] [PubMed]

30. Wang, W.; Eddy, R.; Condeelis, J. The cofilin pathway in breast cancer invasion and metastasis. Nature Rev. Cancer 2007, 7, 429-440. [CrossRef]

31. Hui, M.; Cazet, A.; Nair, R.; Watkins, D.N.; O’Toole, S.A.; Swarbrick, A. The Hedgehog signalling pathway in breast development, carcinogenesis and cancer therapy. Breast Cancer Res. 2013, 15, 203. [CrossRef] [PubMed]

32. Habib, J.G.; O'Shaughnessy, J.A. The hedgehog pathway in triple-negative breast cancer. Cancer Med. 2016, 5, 2989-3006. [CrossRef]

33. Kubo, M.; Nakamura, M.; Tasaki, A.; Yamanaka, N.; Nakashima, H.; Nomura, M.; Kuroki, S.; Katano, M. Hedghog signaling pathway is a new therapeutic target for patients with breast cancer. Cancer Res. 2004, 64, 6071-6074. [CrossRef]

34. Souzaki, M.; Kubo, M.; Kai, M.; Kameda, C.; Tanaka, H.; Taguchi, T.; Tanaka, M.; Onishi, H.; Katano, M. Hedgehog sinnaling pathway mediates the progression of non-invasive breast cancer to invasive breast cancer. Cancer Sci. 2011, 102, 373-381. [CrossRef]

35. Zhou, Y.; Eppenberger-Castori, S.; Eppenberger, U.; Benz, C.C. The NFkB pathway and endocrine-resistant breast cancer. Endocr. Relat. Cancer. 2005, 12, S37-S46. [CrossRef]

36. Zhou, J.; Zhang, H.; Gu, P.; Bai, J.; Margolick, J.B.; Zhang, Y. NFkB pathway inhibitors referentially inhibit breast cancer stem-like cells. Breast Cancer Res. Treat. 2008, 111, 419-427. [CrossRef] [PubMed]

37. Gong, L.; Li, Y.; Nedeljkovic-Kurepa, A.; Sarkar, S.H. Inactivation of NFkB by genistein is mediated via Akt signaling pathway in breast cancer cells. Oncogene 2003, 22, 4702-4709. [CrossRef] [PubMed]

38. Cidado, J.; Park, B.H. Targeting the PI3K/Akt/mTOR pathway for breast cancer therapy. J. Mammary Gland Biol. Neoplasia 2012, 17, 205-216. [CrossRef]

39. López-Knowles, E.; O’Toole, S.A.; McNeil, C.M.; Millar, E.K.; Qiu, M.R.; Crea, P.; Daly, R.J.; Musgrove, E.A.; Sutherland, R.L. PI3K pathway activation in breast cancer is associated with the basal-like phenotype and cancer-specific mortality. Int. J. Cancer 2010, 126, 1121-1131. [CrossRef] [PubMed]

40. Pascual, J.; Turner, N.C. Targeting the PI3-kinase pathway in triple-negative breast cancer. Ann. Oncol. 2019, 1, 1-10. [CrossRef] [PubMed]

41. Paplomata, E.; O'Regan, R. The PI3K/AKT/mTOR pathway in breast cancer: Targets, trials and biomarkers. Ther. Adv. Med. Oncol. 2014, 6, 154-166. [CrossRef]

42. Yang, S.X.; Polley, E.; Lipkowitz, S. New insights on PI3K/AKT pathway alterations and clinical outcomes in breast cancer. Cancer Treat. Rev. 2016, 45, 87-96. [CrossRef] [PubMed]

43. Chandarlapaty, S.; Sakr, R.A.; Giri, D. Frequent mutational activation of the PI3K-AKT pathway in trastuzumab-resistant breast cancer. Clin. Cancer Res. 2012, 18, 6784-6791. [CrossRef]

44. Pierobon, M.; Ramos, C.; Wong, S.; Alex Hodge, K.; Aldrich, J.; Byron, S.; Anthony, S.P.; Robert, N.J.; Northfelt, D.W.; Jahanzeb, M.; et al. Enrichment of PI3K-AKT-mTOR Pathway Activation in Hepatic Metastases from Breast Cancer. Clin. Cancer Res. 2017, 23, 16. [CrossRef] [PubMed]

45. Ghayad, S.E.; Cohen, P.A. Inhibitors of the PI3K/Akt/mTOR pathway: New hope for breast cancer patients. Recent Pat. Anticancer Drug Discov. 2010, 5, 29-57. [CrossRef] [PubMed]

46. Gil, E.M.C. Targeting the PI3K/Akt/mTOR pathway in estrogen receptor-positive breast cancer. Cancer Treat. Rev. 2014, 40, 862-871.

47. Mohinta, S.; Wu, H.; Chaurasia, P.; Watbe, K. Wnt pathway and breast cancer. Front. Biosci. 2007, 12, 4020-4033. [CrossRef] [PubMed]

48. Mukherjee, N.; Battacharya, N.; Alam, N.; Roy, A.; Roychoudhury, S.; Panda, C.K. Subtype-specific alterations of the Wnt signaling pathway in breast cancer: Clinical and prognostic significance. Cancer Sci. 2012, 103, 210-220. [CrossRef] [PubMed]

49. Loh, Y.N.; Hedditch, E.L.; Baker, L.A.; Jary, E.; Ward, R.L.; Ford, C.E. The Wnt signaling pathway is upregulated in an in vitro model of acquired tamoxifen resistant breast cancer. BMC Cancer 2013, 13, 174. [CrossRef] [PubMed]

50. Voduc, K.D.; Nielsen, T.O.; Perou, C.M.; Harrell, J.C.; Fan, C.; Kennecke, H.; Minn, A.J.; Cryns, V.L.; Cheang, M.C. $\alpha$ B-crystallin expression in breast cancer is associated with brain metastasis. npj Breast Cancer 2015, 1, 15014. [CrossRef]

51. Boral, D.; Vishnoi, M.; Liu, H.N.; Yin, W.; Sprouse, M.L.; Scamardo, A.; Hong, D.S.; Tan, T.Z.; Thiery, J.P.; Chang, J.C.; et al. Molecular characterization of breast cancer CTCs associated with brain metastasis. Nat. Commun. 2017, 8, 196. [CrossRef]

52. Chung, B.; Esmaeili, A.A.; Gopalakrishna-Pillai, S.; Murad, J.P.; Andersen, E.S.; Reddy, N.K.; Srinivasan, G.; Armstrong, B.; Chu, C.; Kim, Y.; et al. Human brain metastatic stroma attracts breast cancer cells via chemokines CXCL16 and CXCL12. npj Breast Cancer 2017, 2017, 6. [CrossRef] [PubMed]

53. Giannoudis, A.; Clarke, K.; Zakaria, R.; Varešlija, D.; Farahani, M.; Rainbow, L.; Platt-Higgins, A.; Ruthven, S.; Brougham, K.A.; Rudland, P.S.; et al. A novel panel of differentially-expressed microRNAs in breast cancer brain metastasis may predict patient survival. Sci. Rep. 2019, 9, 18518. [CrossRef] [PubMed] 
54. Ebright, R.Y.; Zachariah, M.A.; Micalizzi, D.S.; Wittner, B.S.; Niederhoffer, K.L.; Nieman, L.T.; Chirn, B.; Wiley, D.F.; Wesley, B.; Shaw, B.; et al. HIF1A signaling selectively supports proliferation of breast cancer in the brain. Nat. Commun. 2020, $11,6311$. [CrossRef] [PubMed]

55. Magnussen, S.N.; Toraskar, J.; Wilhelm, I.; Hasko, J.; Figenschau, S.L.; Molnar, J.; Seppola, M.; Steigen, S.E.; Steigedal, T.S.; Hadler-Olsen, E.; et al. Nephronecin promotes breast cancer brain metastatic colonization via its integrin-binding domains. Sci. Rep. 2020, 10, 12237. [CrossRef] [PubMed]

56. Gong, X.; Hou, Z.; Endsley, M.P.; Gronseth, E.I.; Rarick, K.R.; Jorns, J.M.; Yang, Q.; Du, Z.; Yan, K.; Bordas, M.L.; et al. Interaction of tumor cells and astrocytes promotes breast cancer brain metastases through TGF- $\beta 2 /$ ANGPTL4 axes. npj Precis. Oncol. 2019, 3, 24. [CrossRef] [PubMed]

57. Yu, W.; Huang, W.; Yang, Y.; Qiu, R.; Zeng, Y.; Hou, Y.; Sun, G.; Shi, H.; Leng, S.; Feng, D.; et al. GATA3 recruits UTX for gene transcriptional activation to suppress metastasis of breast cancer. Cell Death Dis. 2019, 10, 832. [CrossRef]

58. Garcia, E.; Luna, I.; Persad, K.L.; Agopsowicz, K.; Jay, D.A.; West, F.G.; Hitt, M.M.; Persad, S. Inhibition of triple negative breast cancer metastasis and invasiveness by novel drugs that target epithelial to mesenchymal transition. Sci. Rep. 2021, $11,11757$. [CrossRef]

59. Li, P.; Cao, S.; Huang, Y.; Zhang, Y.; Liu, J.; Cai, X.; Zhou, L.; Li, J.; Jiang, Z.; Ding, L.; et al. A novel chemical inhibitor suppresses breast cancer cell growth and metastasis through inhibiting HPIP oncoprotein. JCDD 2021, 7, 198. [CrossRef] [PubMed]

60. Feng, Z.; Xia, Y.; Gao, T.; Xu, F.; Lei, Q.; Peng, C.; Yang, Y.; Xue, Q.; Hu, X.; Wang, Q.; et al. The antipsychotic agent trifluoperazine hydrochloride suppresses triple-negative breast cancer tumor growth and brain metastasis by inducing G0/G1 arrest and apoptosis. Cell Death Dis. 2018, 9, 1006. [CrossRef]

61. Yang, H.; Ren, L.; Wang, Y.; Bi, X.; Li, X.; Wen, M.; Zhang, Q.; Yang, Y.; Jia, Y.; Li, Y.; et al. FBI-1 enhanced the resistance of triple-negative breast cancer cells to chemotherapeutic agents via the miR-30c/PXR axis. Cell Death Dis. 2020, 11, 851. [CrossRef] [PubMed]

62. Zhang, X.; Zhang, Z.; Zhang, Q.; Zhang, Q.; Sun, P.; Xiang, R.; Ren, G.; Yang, S. ZEB1 confers chemotherapeutic resistance to breast cancer by activating ATM. Cell Death Dis. 2018, 9, 57. [CrossRef] [PubMed]

63. Luo, H.; Zhou, Z.; Huang, S.; Ma, M.; Zhao, M.; Tang, L.; Quan, Y.; Zeng, Y.; Su, L.; Kim, J.; et al. CHFR regulates chemoresistance in triple-negative breast cancer through destabilizing ZEB1. Cell Death Dis. 2021, 12, 820. [CrossRef] [PubMed]

64. Tran, Q.H.; Hoang, D.H.; Song, M.; Choe, W.; Kang, I.; Kim, S.S.; Ha, J. Melatonin and doxorubicin synergistically enhance apoptosis via autophagy-dependent reduction of AMPK $\alpha 1$ transcription in human breast cancer cells. Exp. Mol. Med. 2021, 53, 1413-1422. [CrossRef] [PubMed]

65. Ghebeh, H.; Al-Khaldi, S.; Olabi, S.; Al-Dhfyan, A.; Al-Mohanna, F.; Barnawi, R.; Tulbah, A.; Al-Tweigeri, T.; Ajarim, D.; Al-Alwan, M. Fascin is involved in the chemotherapeutic resistance of breast cancer cells predominantly via the PI3K/Akt pathway. Br. J. Cancer. 2014, 111, 1552-1561. [CrossRef]

66. Obayemi, J.D.; Salifu, A.A.; Eluu, S.C.; Uzonwanne, V.O.; Jusu, S.M.; Nwazojie, C.C.; Onyekanne, C.E.; Ojelabi, O.; Panye, L.; Moore, C.M.; et al. LHRH-Conjugated drugs as targeted therapeutic agents for the specific targeting and localized treatment of triple negative breast cancer. Sci. Rep. 2020, 10, 8212. [CrossRef] [PubMed]

67. Bai, L.Y.; Chiu, C.F.; Chu, P.C.; Lin, W.Y.; Chiu, S.J.; Weng, J.R. A triterpenoid from wild bitter gourd inhibits breast cancer cells. Sci. Rep. 2016, 6, 22419. [CrossRef]

68. Iqbal, J.; Abbasi, B.A.; Mahmood, T.; Kanwal, S.; Ali, B.; Khalil, T. Plant-derived anticancer agents: A green anticancer approach. Asian Pac. J. Trop. Biomed. 2017, 3, 1-23. [CrossRef]

69. Kooti, W.; Servatyari, K.; Behzadifar, M.; Samani, M.A.; Sadeghi, F.; Nouri, B.; Marzouni, H.Z. Effective medicinal plant in cancer treatment, Part 2: Review study. J. Evid.-Based Complementary Altern. Med. 2017, 22, 982-995. [CrossRef] [PubMed]

70. Shareef, M.; Ashraf, M.A.; Sarfraz, M. Natural cures of breast cancer treatment. Saudi Pharm. J. 2016, 24, 233-240. [CrossRef] [PubMed]

71. Driggins, S.N.; Whalen, M.; Myles, L.E. The inhibitory effect of Echinacea purpurea and Echinacea pallida on BT-549 and natural killer cells. MOJ Cell Sci. Rep. 2017, 4, 00091.

72. Paredes, D.E.E.; Garrido, J.C.; Eutimio, M.A.M.; Rodrígue, O.P.M.; Flores, M.E.J.; Pichardo, C.O. Echinacea Angustifolia DC Extract Induces Apoptosis and Cell Cycle Arrest and Synergizes with Paclitaxel in the MDA-MB-231 and MCF-7 Human Breast Cancer Cell Lines. Nutr. Cancer. 2020, 5, 1-20. [CrossRef] [PubMed]

73. Shang, A.; Cao, S.Y.; Xu, X.Y.; Gan, R.Y.; Tang, G.Y.; Corke, H.; Mavumengwana, V.; Li, H.B. Bioactive compounds nad biological functions of Garlic (Allium sativum L.). Foods 2019, 8, 246. [CrossRef]

74. Velsankar, K.; Preethi, R.; Jeevan Ram, P.S.; Ramesh, M.; Sudhahar, S. Evaluations of biosynthesized Ag nanoparticles via Allium sativum flower extract in biological applications. Appl. Nanosci. 2020, 10, 3675-3691. [CrossRef]

75. Hemalatha, P.; Premnath, A. Study on silver nanoparticle encapsulated curcumin for anticancer activity. World. J. Pharm. Res. 2016, 5, 953-958.

76. Minafra, L.; Porcino, N.; Bravatà, V.; Gaglio, D.; Bonanomi, M.; Amore, E.; Cammarata, F.P.; Russo, G.; Militello, C.; Savoca, G.; et al. Radiosensitizing effect of curcuminloaded lipid nanoparticles in breast cancer cells. Sci. Rep. 2019, 9, 11134. [CrossRef] [PubMed]

77. Poompavai, S.; Gowri Sree, V. Anti-proliferative efficiency of pulsed electric field treated curcuma longa (Turmeric) extracts on breast cancer cell lines. IETE J. Res. 2020, 1-15. [CrossRef] 
78. Ahmad, R.; Sirvastava, A.N.; Khan, M.A. Evaluation of in vitro anticancer activity of rhizome of curcuma longa against human breast cancer and Vero cell lines. Int. J. Bot. Studies. 2016, 1, 1-6.

79. Lou, C.; Zhu, Z.; Zhao, Y.; Zhu, R.; Zhao, H. Arctigenin, a liganan from Arctium lappa L., inhibits metastasis of human breast cancer cells through the downregulation of MMP-2/-9 and heparanase in MDA-MB-231 cells. Oncol. Rep. 2016, 37, 179-184. [CrossRef]

80. Sun, Q.; Liu, K.; Shen, X.; Jin, W.; Jiang, L.; Sheikh, S.M.; Hu, Y.; Huang, Y.; Lappaol, F. A Novel Anticancer Agent Isolated from Plant Arctium Lappa, L. Mol. Cancer Ther. 2014, 13, 49-59. [CrossRef]

81. Ghafari, F.; Rajabi, M.R.; Mazoochi, T.; Taghizadeh, M.; Nikzad, H.; Atlasi, M.A.; Taherian, A. Comparing Apoptosis and Necrosis Effects of Arctium Lappa Root Extract and Doxorubicin on MCF7 and MDA-MB-231 Cell Lines. APJCP 2017, 18, 795-802.

82. Li, X.; Lin, Y.Y.; Tan, J.Y.; Liu, K.L.; Shen, X.L.; Hu, Y.J.; Yang, R.Y. Lappaol F, an anticancer agent, inhibits YAP via transcriptional and post-translational regulation. Pharm. Biol. 2021, 59, 619-628. [CrossRef]

83. Lefojane, R.P.; Sone, B.T.; Matinise, N.; Saleh, K.; Direko, P.; Mfengwana, P.; Mashele, S.; Maaza, M.; Sekhoacha, M.P. CdO/CdCO3 nanocomposite physical properties and cytotoxicity against selected breast cancer cell lines. Sci. Rep. 2021, 11, 30. [CrossRef]

84. Yue, G.G.L.; Xie, S.; Lee, J.K.M.; Kwok, H.F.; Gao, S.; Nian, Y.; Wu, X.X.; Wong, C.K.; Qiu, M.H.; Bik-San Lau, C. New potential beneficial effects of actein, a triterpene glycoside isolated from Cimicifuga species, in breast cancer treatment. Sci. Rep. 2016, 6, 35263. [CrossRef] [PubMed]

85. Kong, Y.; Li, F.; Nian, Y.; Zhou, Z.; Yang, R.; Qiu, M.H.; Chen, C. KHF16 is a Leading Structure from Cimicifuga foetida that Suppresses Breast Cancer Partially by Inhibiting the NF-kB Signaling Pathway. Theranostics 2016, 6, 875-886. [CrossRef] [PubMed]

86. Nordin, N.; Yeap, S.K.; Rahman, H.S.; Zamberi, N.R.; Abu, N.; Mohamad, N.E.; How, C.W.; Masarudin, M.J.; Abdullah, R.; Alitheen, N.B. In vitro cytotoxicity and anticancer effects of citral nanostructured lipid carrier on MDA MBA-231 human breast cancer cell. Sci. Rep. 2019, 9, 1614. [CrossRef] [PubMed]

87. Armas, J.P.R.; Acevedo, J.L.A.; Pacheco, M.P.; Calderón, O.H.; Sánchez, J.M.O.; Armas, A.R.; Calva, J.; Luna, A.C.; Vargas, J.H. The Essential Oil of Cymbopogon citratus Stapt and Carvacrol: An Approach of the Antitumor Effect on 7,12-Dimethylbenz-[ $\alpha]-$ anthracene (DMBA)-Induced Breast Cancer in Female Rats. Molecules 2020, 25, 3284. [CrossRef]

88. Thangama, R.; Sathuvan, M.; Poongodi, A.; Suresh, V.; Pazhanichamy, K.; Sivasubramanian, S.; Kanipandian, N.; Ganesan, N.; Rengasamy, R.; Thirumurugan, R.; et al. Activation of intrinsic apoptotic signaling pathway in cancer cells by Cymbopogon citratus polysaccharide fractions. Carbohydr. Polym. 2014, 107, 138-150. [CrossRef]

89. Qian Mao, Q.; Yu Xu, X.; Yu Cao, S.; You Gan, R.; Corke, H.; Beta, T.; Bin Li, H. Bioactive Compounds and Bioactives of Giinger (Zingiber officinale). Foods 2019, 8, 185.

90. Zhao, L.; Rupji, M.; Choudhary, I.; Osan, R.; Kapoor, S.; Zhang, H.J.; Yang, C.; Aneja, R. Efficacy based ginger finger printing reveals potential antiproliferative analytes for triple negative breast cancer. Sci. Rep. 2020, 10, 19182. [CrossRef]

91. Elkady, A.I.; Abuzinadah, O.A.; Baeshen, N.A.; Rahmy, T.R. Differential Control of Growth, Apoptotic Activity, and Gene Expression in Human Breast Cancer Cells by Extracts Derived from Medicinal Herbs Zingiber officinale. J. Biomed. Biotechnol. 2012, 5, 614356.

92. Rahman, S.; Salehin, F.; Iqbal, A. RETRACTED ARTICLE: In vitro antioxidant and anticancer activity of young Zingiber officinale against human breast carcinoma cell lines. BMC Complementary Altern. Med. 2011, 11, 76. [CrossRef]

93. Alsamri, H.; Athamneh, K.; Pintus, G.; Eid, A.H.; Iratni, R. Pharmacological and Antioxidant Activities of Rhus coriaria L. (Sumac). Antioxidants 2021, 10, 73. [CrossRef] [PubMed]

94. El Hasasna, H.; Saleh, A.; Al Samri, H.; Athamneh, K.; Attoub, S.; Arafat, K.; Benhalilou, N.; Alyan, S.; Viallet, J.; Al Dhaheri, Y.; et al. Rhus coriaria suppresses angiogenesis, metastasis and tumor growth of breast cancer through inhibition of STAT3, NFkB and nitric oxide pathways. Sci. Rep. 2016, 6, 2114. [CrossRef]

95. El Hasasna, H.; Athamneh, K.; Al Samri, H.; Karuvantevida, N.; Al Dhaheri, Y.; Hisaindee, S.; Ramadan, G.; Al Tamimi, N.; AbuQamar, S.; Eid, A.; et al. Rhus coriaria induces senescence and autophagic cell death in breast cancer cells through a mechanism involving p38 and ERK1/2 activation. Sci. Rep. 2015, 5, 13013. [CrossRef] [PubMed]

96. Kubatka, P.; Kello, M.; Kajo, K.; Samec, M.; Liskova, A.; Jasek, K.; Koklesova, L.; Kuruc, T.; Adamkov, M.; Smejkal, K.; et al. Rhus coriaria L. (Sumac) Demonstrates Oncostatic Activity in the Therapeutic and Preventive Model of Breast Carcinoma. Int. J. Mol. Sci. 2021, 22, 183. [CrossRef]

97. Majumder, M.; Debnath, S.; Gajbhiye, R.L.; Saikia, R.; Gogoi, B.; Samanta, S.K.; Das, D.K.; Biswas, K.; Jaisankar, P.; Mukhopadhyay, R. Ricinus communis L. fruit extract inhibits migration/invasion, induces apoptosis in breast cancer cells and arrests tumor progression in vivo. Sci. Rep. 2019, 9, 14493. [CrossRef]

98. Abdul, W.M.; Hajrah, N.H.; Sabir, J.S.M.; Al-Garni, S.M.; Sabir, M.J.; Kabli, S.A.; Saini, K.S.; Bora, R.S. Therapeutic role of Ricinus communis L. and its bioactive compounds in disease prevention and treatment. Asian Pac. J. Trop. Med. 2018, 11, 177-185. [CrossRef]

99. Shobha, N.; Nanda, N.; Giresha, A.S.; Manjappa, P.; Dharmappa, K.K.; Nagabhushana, B.M. Synthesis and characterization of Zinc oxide nanoparticles utilizing seed source of Ricinus communis and study of its antioxidant, antifungal and anticancer activity. Mater. Sci. Eng. 2019, 97, 842-850. [CrossRef]

100. Ghate, N.B.; Das, A.; Chaudhuri, D.; Panja, S.; Mandal, N. Sundew plant, a potential source of anti-inflammatory agents, selectively induces G2/M arrest and apoptosis in MCF-7 cells through upregulation of p53 and Bax/Bcl-2 ratio. Cell Death Dis. 2016, 2, 15062. [CrossRef] [PubMed] 
101. Afsar, T.; Trembley, J.H.; Salomon, C.E.; Razak, S.; Khan, M.R.; Ahmed, K. Growth inhibition and apoptosis in cancer cells induced by polyphenolic compounds of Acacia hydaspica: Involvement of multiple signal transduction pathways. Sci. Rep. 2016, 6, 23077. [CrossRef] [PubMed]

102. Peng, Z.; Wang, Y.; Fan, J.; Lin, X.; Liu, C.; Xu, Y.; Ji, W.; Yan, C.; Su, C. Costunolide and dehydrocostuslactone combination treatment inhibit breast cancer by inducing cell cycle arrest and apoptosis through c-Myc/p53 and AKT/14-3-3 pathway. Sci. Rep 2017, 7, 41254. [CrossRef] [PubMed]

103. Robinson, A.; Kumar, T.V.; Sreedhar, E.; Naidu, V.G.M.; Krishna, S.R.; Babu, K.S.; Srinivas, P.V.; Rao, J.M. A new sesquiterpene lactone from the roots of Saussurea lappa: Structure-anticancer activity study. Bioorg. Med. Chem. Lett. 2008, 18, 4015-4017. [CrossRef] [PubMed]

104. Choi, Y.K.; Cho, S.G.; Woo, S.M.; Yun, J.Y.; Jo, J.; Kim, W.Y.; Shin, Y.C.; Ko, S.G. Saussurea lappa Clarke-Derived Costunolide Prevents TNF $\alpha$-Induced Breast Cancer Cell Migration and Invasion by Inhibiting NF- $\kappa$ B Activity. ECAM 2013, 2013. [CrossRef]

105. Babykutty, B.; Padikkala, J.; Sathiadevan, P.P.; Vijayakurup, V.; Azis, T.K.A.; Srinivas, P.; Gopala, S. Apoptosis induction of centella asiatica on human breast cancer cells. Afr. J. Trad. CAM 2009, 6, 9-16. [CrossRef]

106. Gou, X.; Bai, H.; Liu, L.; Chen, H.; Shi, Q.; Chang, L.; Ding, M.; Shi, Q.; Zhou, M.; Chen, W.; et al. Asiatic Acid Interferes with Invasion and Proliferation of Breast Cancer Cells by Inhibiting WAVE3 Activation through PI3K/AKT signaling pathway. Biomed Res. Int. 2020, 1874387, 12. [CrossRef]

107. Pittella, F.; Dutra, R.C.; Junior, D.D.; Lopes, M.T.P.; Barbosa, N.R. Antioxidant and Cytotoxic Activities of Centella asiatica (L) Urb. Int. J. Mol. Sci. 2009, 10, 3713-3721. [CrossRef]

108. Xu, D.; Hua Lin, T.; Ren Yeh, C.; Cheng, M.A.; Min Chen, L.; Chang, C.; Yeh, S. The Wedelolactone Derivative Inhibits Estrogen Receptor-Mediated Breast, Endometrial, and Ovarian Cancer Cells Growth. BioMed Res. Int. 2014, 713263, 11. [CrossRef]

109. Arya, R.K.; Singh, A.; Yadav, N.K.; Cheruvu, S.H.; Hossain, Z.; Meena, S.; Maheshwari, S.; Singh, A.K.; Shahab, U.; Sharma, C.; et al. Anti-breast tumor activity of Eclipta extract in-vitro and in-vivo: Novel evidence of endoplasmic reticulum specific localization of Hsp60 during apoptosis. Sci. Rep. 2015, 5, 18457. [CrossRef] [PubMed]

110. Huntimer, E.; Halaweish, F.; Chase, C. Proliferative Activity of Echinacea angustifolia root extracts on cancer cells: Interference with Doxorubicin Cytotoxicity. Chem. Biodivers. 2006, 3, 695-703. [CrossRef] [PubMed]

111. Aćimović, M.; Čabarkapa, I.; Cvetković, M.; Stanković, J.; Kiprovski, B.; Gvozdenac, S.; Puvača, N. Cymbopogon citratus (DC.) Staph: Chemical composition, antimicrobial and antioxidant activities, use in medicinal and cosmetic purpose. J. Agron. Technol. Eng. Manag. 2019, 2, 344-360.

112. Mao, Q.Q.; Xu, X.Y.; Cao, S.Y.; Gan, R.Y.; Corke, H.; Beta, T.; Li, H.B. Bioactive Compounds and Bioactivities of Ginger (Zingiber officinale Roscoe). Foods 2019, 8, 185. [CrossRef] [PubMed]

113. Yue, S.J.; Liu, J.; Feng, W.W.; Zhang, F.L.; Chen, J.X.; Xin, L.T.; Peng, C.; Guan, H.S.; Wang, C.Y.; Yan, D. System Pharmacologybased dissection of the synergistic mechanism of Huangqi and Huanglian for diabetes mellitus. Front. Pharmacol. 2017, 8, 694. [CrossRef] [PubMed]

114. Huang, C.; Li, R.; Shi, W.; Huang, Z. Discovery of the Anti-Tumor Mechanism of Calycosin Against Colorectal Cancer by Using System Pharmacology Approach. Med. Sci. Monit. 2019, 25, 5589-5593. [CrossRef] [PubMed]

115. Wang, J.H.; Li, Y.; Yang, Y.F.; Du, J.; Zhao, M.Q.; Lin, F. Systems pharmacology dissection of multi-scale mechanisms of action for herbal medicines in treating rheumatoid arthritis. Mol. Pharmacol. 2017, 14, 7b00505. [CrossRef] [PubMed]

116. Huang, Y.; Fang, J.; Lu, W.; Wang, Z.; Wang, Q.; Hou, Y.; Jiang, X.; Reizes, O.; Lathia, J.; Nussinov, R.; et al. A Systems Pharmacology Approach Uncovers Wogonoside as an Angiogenesis Inhibitor of Triple-Negative Breast Cancer by Targeting Hedgehog Signaling. Cell Chem. Biol. 2019, 26, 1143-1158. [CrossRef] [PubMed]

117. Hodaei, M.; Rahimmalek, M.; Behbahani, M. Anticancer drug discovery from Iranian Chrysanthemum cultivars through system pharmacology exploration and experimental validation. Sci. Rep. 2021, 11, 11767. [CrossRef] [PubMed]

118. Sakle, N.S.; More, S.A.; Mokale, S.N. A network pharmacology-based approach to explore potential targets of Caesalpinia pulcherima: An updated prototype in drug discovery. Sci. Rep. 2020, 10, 17217. [CrossRef]

119. Fleisher, B.; Andrews, K.; Brown, A.A.; Ait-Oudhia, S. Application of pharmacometrics and quantitative systems pharmacology to cancer therapy: The example of luminal A breast cancer. Pharmacol. Res. 2017, 2017, 1-10. [CrossRef] [PubMed]

120. Zhanga, S.; Gonga, C.; Ruiz-Martinez, A.; Wanga, H.; Davis-Marcisak, E.; Deshpande, A.; Popel, A.S.; Fertig, E.J. Integrating single cell sequencing with a spatial quantitative systems pharmacology model spQSP for personalized prediction of triple-negative breast cancer immunotherapy response. Immunoinformatics 2021, 1-2, 100002. [CrossRef] [PubMed]

121. Chelliah, V.; Lazarou, G.; Bhatnagar, S.; Gibbs, J.P.; Nijsen, M.; Ray, A.; Stoll, B.; Thompson, R.A.; Gulati, A.; Soukharev, S.; et al. Quantitative Systems Pharmacology Approaches for Immuno-Oncology: Adding Virtual Patients to the Development Paradigm. Clin. Pharmacol. Ther. 2020, 1-14. [CrossRef]

122. Sessions, Z.; Sanchez-Cruz, N.; Prieto-Martinez, F.D.; Lves, V.M.; Santos, H.P., Jr.; Muratov, E.; Tropsha, A.; Medina-Franco, J.L. Recent progress on cheminformatics approaches to epigenetic drug discovery. Drug Discov. 2020, 25, 2268-2276. [CrossRef] [PubMed]

123. Grixti, J.M.; Hagan, S.; Day, P.J.; Kell, D.B. Enhancing Drug Efficacy and Therapeutic Index through Cheminformatics-Based Selection of Small molecule Binary Weapons That Improve Transporter-Mediated Targeting: A Cytotoxicity System Based on Gemcitabine. Front. Pharmacol. 2017, 8, 155. [CrossRef] [PubMed] 
124. Zhu, Q.; Tao, C.; Shen, F.; Chute, C.G. Exploring the pharmacogenomics knowledge base (pharm GKB) for repositioning breast cancer drugs by leveraging web ontology language $(\mathrm{OWL})$ and cheminformatics approaches. Pac. Symp. Biocomput. 2014, 172-182.

125. Medina-Franco, J.L.; Saldívar-González, F.I. Cheminformatics to Characterize Pharmacologically Active Natural Products. Biomolecules 2020, 10, 1566. [CrossRef]

126. Mohanraj, K.; Karthikeyan, B.S.; Vivek-Ananth, R.P.; Chand, R.B.; Aparna, S.R.; Mangalapandi, P.; Samal, A. IMPPAT: A curated database of Indian Medicinal Plants, Phytochemistry and Therapeutics. Sci. Rep. 2018, 8, 4329. [CrossRef] [PubMed]

127. Wu, Y.; Zhang, F.; Yang, K.; Fang, S.; Bu, D.; Li, H.; Sun, L.; Hu, H.; Gao, K.; Wang, W.; et al. SymMap: An integrative database of traditional Chinese medicine enhanced by symptom mapping. Nucleic Acids Res. 2018, 47, D1110-D1117. [CrossRef] [PubMed]

128. Venugopalan Nair, S.N.; Ved, D.K.; Ravikumar, K.; Tabassum, I.F.; Sureshchandra, S.T.; Somasekhar, B.S.; Sathya, S.; Barve, V.; Naveen, S.; Payyappalimana, U.; et al. Indian Medicinal Plants Database (IMPLAD) and Threatened Medicinal Plants of India. In Conservation and Utilization of Threatened Medicinal Plants; Rajasekharan, P., Wani, S., Eds.; Springer: Cham, Switzerland, 2020.

129. Zeng, X.; Zhang, P.; Wang, Y.; Qin, C.; Chen, S.; He, W.; Tao, L.; Tan, Y.; Gao, D.; Wang, B.; et al. CMAUP: A database of collective molecular activities of useful plants. Nucleic Acids Res. 2018, 47, D1118-D1127. [CrossRef]

130. Jia, C.Y.; Li, J.Y.; Hao, G.F.; Yang, G.F. A drug-likeness toolbox facilitates ADMET study in drug discovery. Drug Discov. 2019, 25, 248-258. [CrossRef] [PubMed]

131. Keefe, L.J.; Stoll, V.S. Accelerating pharmaceutical structure-guided drug design: A successful model. Drug Discov. 2019, 24, 318-377. [CrossRef] [PubMed]

132. Ferreira, L.L.G.; Andricopulo, A.D. ADMET modeling approaches in drug discovery. Drug Discov. 2019, 24, 1157-1165. [CrossRef]

133. Fang, J.; Liu, C.; Wang, Q.; Lin, P.; Cheng, F. In silico polypharmacology of natural products. Brief. Bioinform. 2018, 19, 1153-1171. [CrossRef] [PubMed]

134. Yang, B.; Mao, J.; Gao, B.; Lu, X. Computer-Assisted Drug Virtual Screening Based on the Natural Product Databases. Curr. Pharm. Biotechnol. 2019, 20, 293-301. [CrossRef]

135. Khan, T.; Ali, M.; Khan, A.; Nisar, P.; Jan, S.A.; Afridi, S.; Shinwari, Z.K. Anticancer plants: A review of the active phytochemicals, applications in animal models, and regulatory aspects. Biomolecules 2020, 10, 47. [CrossRef] [PubMed]

136. Gaur, R.; Yadav, D.K.; Kumar, S.; Darokar, M.P.; Khan, F.; Bhakuni, R.S. Molecular modeling based synthesis and evaluation of in vitro anticancer activity of indolyl chalcones. Curr. Top. Med. Chem. 2015, 15, 1003-1012. [CrossRef]

137. Li, Y.; Wang, J.; Lin, F.; Yang, Y.; Chen, S.S. A Methodology for Cancer Therapeutics by Systems Pharmacology-Based Analysis: A Case Study on Breast Cancer-Related Traditional Chinese Medicines. PLoS ONE 2017, 12, e0169363. [CrossRef] [PubMed]

138. Jeyasri, R.; Muthuramalingam, P.; Suba, V.; Ramesh, M.; Chen, J.-T. Bacopa monnieri and Their Bioactive Compounds Inferred Multi-Target Treatment Strategy for Neurological Diseases: A Cheminformatics and System Pharmacology Approach. Biomolecules 2020, 10, 536. [CrossRef] [PubMed]

139. Saha, P.S.; Sarkar, S.; Jeyasri, R.; Muthuramalingam, P.; Ramesh, M.; Jha, S. In vitro propagation, phytochemical and neuropharmacological profiles of Bacopa monnieri (L.) Wettst: A review. Plants 2020, 9, 411. [CrossRef]

140. Umadevi, M.; Sampath Kumar, K.P.; Bhowmik, D.; Duraive, S. Traditionally Used Anticancer Herbs in India. J. Med. Plants Stud. 2013, 1, 56-74.

141. Mustafa, G.; Arif, R.; Atta, A.; Sharif, S.; Jamil, A. Bioactive Compounds from Medicinal Plants and Their Importance in Drug Discovery in Pakistan. Matrix Sci. Pharma 2017, 1, 17-26. [CrossRef]

142. Subramaniam, S.; Selvaduray, K.R.; Radhakrishnan, A.K. Bioactive Compounds: Natural Defense Against Cancer? Biomolecules 2019, 9, 758. [CrossRef]

143. Baraya, Y.S.; Kah Keng, W.; Nik Soriani, Y. The Immunomodulatory Potential of Selected Bioactive Plant -Based Compounds in Breast Cancer: A Review. Anticancer Agents Med. Chem. 2017, 17, 770-783. [CrossRef]

144. Gezici, S.; Sekeroglu, N. Regulation of Micrornas by Natural Products and Bioactive Compounds Obtained from Common Medicinal Plants: Novel Strategy in Cancer Therapy. Indian J. Pharm. Educ. Res. 2017, 51, S483-S488. [CrossRef]

145. Zou, H.; Li, Y.; Liu, X.; Wu, Z.; Li, J.; Ma, Z. Roles of plant-derived bioactive compounds and related microRNAs in cancer therapy. Phytother. Res. 2020, 35, 1176-1186. [CrossRef] [PubMed] 